\title{
Contribution of very short-lived substances to stratospheric bromine loading: uncertainties and constraints
}

\author{
J. Aschmann ${ }^{1}$ and B.-M. Sinnhuber ${ }^{2}$ \\ ${ }^{1}$ Institute of Environmental Physics, University of Bremen, Bremen, Germany \\ ${ }^{2}$ Institute for Meteorology and Climate Research, Karlsruhe Institute of Technology, Karlsruhe, Germany \\ Correspondence to: J. Aschmann (jan.aschmann@iup.physik.uni-bremen.de)
}

Received: 23 October 2012 - Published in Atmos. Chem. Phys. Discuss.: 22 November 2012

Revised: 21 January 2013 - Accepted: 22 January 2013 - Published: 1 February 2013

\begin{abstract}
Very short-lived substances (VSLS) still represent a major factor of uncertainty in the quantification of stratospheric bromine loading. One of the major obstacles for short-lived source gases in contributing to the stratosphere is generally thought to be loss of inorganic bromine $\left(\mathrm{Br}_{\mathrm{y}}\right)$ in the tropical tropopause layer (TTL) due to dehydration. We use sensitivity calculations with a three-dimensional chemistry transport model comprising a consistent parametrization of convective transport and a comprehensive chemistry scheme to investigate the associated processes. The model considers the two most important bromine VSLS, bromoform $\left(\mathrm{CHBr}_{3}\right)$ and dibromomethane $\left(\mathrm{CH}_{2} \mathrm{Br}_{2}\right)$. The organic bromine source gases as well as the resulting profile of inorganic bromine in the model are consistent with available observations. In contrast to its organic precursors, $\mathrm{Br}_{\mathrm{y}}$ is assumed to have a significant sorption capacity regarding sedimenting liquid or frozen particles thus the fraction of intact source gases during their ascent through the TTL is a critical factor. We find that source gas injection is the dominant pathway into the stratosphere, about $50 \%$ of $\mathrm{CHBr}_{3}$ and $94 \%$ of $\mathrm{CH}_{2} \mathrm{Br}_{2}$ is able to overcome the cold point tropopause at approximately $17 \mathrm{~km}$ altitude, modulated by the interannual variability of the vertical transport efficiency. In fact, our sensitivity calculations indicate that the extent of source gas injection of $\mathrm{CHBr}_{3}$ is highly sensitive to the strength of convection and large-scale ascent; in contrast, modifying the photolysis or the destruction via $\mathrm{OH}$ yields a significantly smaller response. In principle, the same applies as well to $\mathrm{CH}_{2} \mathrm{Br}_{2}$, though it is considerably less responsive due to its longer lifetime. The next important aspect we identified is that the partitioning of available $\mathrm{Br}_{\mathrm{y}}$ from short-lived sources is clearly shifted away from $\mathrm{HBr}$, according to our current state of knowledge the only
\end{abstract}

member of the $\mathrm{Br}_{\mathrm{y}}$ family which is efficiently adsorbed on ice particles. This effect is caused by very efficient heterogeneous reactions on ice surfaces which reduce the $\mathrm{HBr} / \mathrm{Br}_{\mathrm{y}}$ fraction below $15 \%$ at the tropical tropopause. Under these circumstances there is no significant loss of $\mathrm{Br}_{\mathrm{y}}$ due to dehydration in the model, VSLS contribute fully to stratospheric bromine. In addition, we conduct several sensitivity calculations to test the robustness of this result. If heterogeneous chemistry is ignored, the $\mathrm{HBr} / \mathrm{Br}_{\mathrm{y}}$ fraction exceeds $50 \%$ and about $10 \%$ of bromine from VSLS is scavenged. Dehydration plays a minor role for $\mathrm{Br}_{\mathrm{y}}$ removal under the assumption that $\mathrm{HOBr}$ is efficiently adsorbed on ice as well since the heterogeneous reactions alter the partitioning equilibrium of $\mathrm{Br}_{\mathrm{y}}$ in favor of HOBr. In this case, up to $12 \%$ of bromine from VSLS is removed. Even in the extreme and unrealistic case that adsorbed species on ice particles are instantaneously removed the maximum loss of bromine does not exceed $25 \%$. Assuming 6 parts per trillion by volume (pptv) of bromine short-lived source gases in convective updrafts, a value that is supported by observational data, we find a most likely contribution of VSLS to stratospheric bromine in the range of 4.5-6 pptv.

\section{Introduction}

In recent years, more and more attention has been paid to very short-lived substances (VSLS) as important contributors to stratospheric bromine loading. A little more than a decade ago it was thought that these species, whose average tropospheric lifetime is less than six months, are unable to reach the stratosphere and are therefore not relevant as sources for 
ozone-depleting substances. However, we now have plenty of observational evidence and simulation results suggesting that the stratospheric mixing ratio of inorganic bromine $\left(\mathrm{Br}_{\mathrm{y}}\right)$ in the range of 19.5-24.5 pptv (Montzka and Reimann, 2011) cannot be solely explained with the well known and considerably longer-lived source gases such as methyl bromide $\left(\mathrm{CH}_{3} \mathrm{Br}\right)$, Halon-1211 $\left(\mathrm{CBrClF}_{2}\right)$ or Halon-1301 $\left(\mathrm{CBrF}_{3}\right)$; a significant part must originate from other sources, most likely VSLS.

Satellite observations of bromine monoxide $(\mathrm{BrO})$ indicate a contribution of VSLS to stratospheric inorganic bromine $\left(\mathrm{Br}_{\mathrm{y}}^{\mathrm{VSLS}}\right)$ in the range of 3-10 pptv (Sinnhuber et al., 2005; Sioris et al., 2006; McLinden et al., 2010; Salawitch et al., 2010); a similar study with $\mathrm{BrO}$ data from balloon-borne instruments suggests $4.1 \mathrm{pptv}$ (Dorf et al., 2006). Several modeling studies found a wide range for $\mathrm{Br}_{\mathrm{y}}^{\mathrm{VSLS}}$, though the inherent differences between the approaches make a direct comparison difficult: 0.8-3 pptv (Dvortsov et al., 1999; Nielsen and Douglass, 2001; Sinnhuber and Folkins, 2006; Kerkweg et al., 2008; Gettelman et al., 2009; Aschmann et al., 2009; Hossaini et al., 2010); 4.8-5.2 pptv (Schofield et al., 2011; Liang et al., 2010; Aschmann et al., 2011; Hossaini et al., 2012) and 6-7 pptv (Warwick et al., 2006). The most important bromine VSLS are bromoform $\left(\mathrm{CHBr}_{3}\right)$ and dibromomethane $\left(\mathrm{CH}_{2} \mathrm{Br}_{2}\right)$ with an average tropospheric lifetime of 24 and 123 days and an average mixing ratio in the marine boundary layer (MBL) of 1.6 and $1.1 \mathrm{pptv}$, respectively (Montzka and Reimann, 2011). However, some studies suggest that also the combination of several other minor VSLS may contribute a significant amount of bromine (e.g. Warwick et al., 2006; Hossaini et al., 2012; Brinckmann et al., 2012).

Despite increased scientific effort in recent years, two major uncertainties still challenge the quantification of $\mathrm{Br}_{\mathrm{y}}^{\mathrm{VSLS}}$. The first point is the emission strength of VSLS. Predominantly of natural origin, produced by marine lifeforms such as macroalgae and certain phytoplankton groups, local mixing ratios of the short-lived source gases in the MBL can be much higher than the above mentioned average values, especially in coastal or upwelling areas (e.g. Carpenter and Liss, 2000; Quack and Wallace, 2003; Yokouchi et al., 2005; Butler et al., 2007; Brinckmann et al., 2012). Due to the scarcity of constraining observational data the spread of emission estimates is therefore no surprise (e.g. $400-1400 \mathrm{Gg} \mathrm{Br} \mathrm{yr}^{-1}$ for $\mathrm{CHBr}_{3}$; Yokouchi et al., 2005; Warwick et al., 2006; Butler et al., 2007; Carpenter et al., 2009; O’Brien et al., 2009; Liang et al., 2010; Ordóñez et al., 2012) and reflects our lack of knowledge in this area.

The second point is the vertical transport. There is general agreement that tropical deep convection is the most important pathway for air parcels into stratosphere, lofting them above the level of zero radiative heating (LZRH) where they can ascend further (e.g. Corti et al., 2005; Sinnhuber and Folkins, 2006; Fueglistaler et al., 2009). The critical question is, what fraction of short-lived source gases reaches the stratosphere intact, commonly referred to as source gas injection (SGI). A major controlling factor in this respect is the collocation of VSLS emissions and deep convective transport, which can be observed for example in the Western-Pacific region, arguably one of the most important pathways for VSLS into the stratosphere (e.g. Levine et al., 2007; Butler et al., 2007; Aschmann et al., 2009; Pisso et al., 2010; Bergman et al., 2012). Another important aspect is the varying photochemical degradation efficiency of VSLS, especially in relation to ambient pollutants (e.g. Krysztofiak et al., 2012).

The corresponding contrary mechanism, i.e. the amount of product gases produced by the decay of short-lived source gases that enter the stratosphere, is called product gas injection (PGI). The relative fraction of SGI/PGI is a critical factor, as several species among the inorganic bromine product gases are soluble and can be scavenged by falling rain or ice particles, in contrast to their insoluble organic precursors (e.g. Law and Sturges, 2007). In this context, the efficient dehydration of tropospheric air in the exceptional cold tropical tropopause layer (TTL) plays an important role, as the drastic "freeze-drying" of ascending air parcels is suspected to remove a significant share of soluble tracers as well. However, the dehydration mechanism itself is a complex phenomena and still subject to current discussions (e.g. Sherwood and Dessler, 2001; Holton and Gettelman, 2001; Fueglistaler et al., 2005, 2009). Most modeling studies that investigate the contribution of $\mathrm{Br}_{\mathrm{y}}^{\mathrm{VSLS}}$ assume a fixed washout lifetime for $\mathrm{Br}_{\mathrm{y}}$, typically in the range of 10-30 days in the troposphere and above (Dvortsov et al., 1999; Nielsen and Douglass, 2001; Sinnhuber and Folkins, 2006; Warwick et al., 2006; Hossaini et al., 2010) suggesting that $60-80 \%$ of $\mathrm{Br}_{\mathrm{y}}^{\mathrm{VSLS}}$ is lost due to dehydration. Models that use a more complex representation of the dehydration process show a significantly lower impact on $\mathrm{Br}_{\mathrm{y}}^{\mathrm{VSLS}}$, in the order of 5-8\% in the TTL (Liang et al., 2010; Aschmann et al., 2011). In fact, when taking into account heterogeneous reactions on particles or aerosols as suggested by, e.g. von Glasow et al. (2004) or Salawitch (2006) our previous study indicates that loss of $\mathrm{Br}_{\mathrm{y}}$ due to scavenging in the TTL vanishes almost completely (Aschmann et al., 2011).

In this study, we mainly concentrate on the latter aspect, the loss of inorganic bromine due to scavenging, as this process is thought to be one of the major obstacles for short-lived source gases in contributing to stratospheric bromine loading and is of critical importance for assessing the ozone depletion potential for VSLS. In extension of our previous modeling work in Aschmann et al. (2011), we present an ensemble of sensitivity calculations with a three-dimensional (3-D) chemistry transport model (CTM) to investigate the intricate relationship among the involved processes controlling direct source gas injection of VSLS and the impact of dehydration in the TTL on inorganic bromine in more detail. 
Table 1. Gas-phase, heterogeneous and photolytic reactions that control the partitioning of inorganic bromine in the model. Arrhenius Afactor, activation temperature E/R, uptake coefficient $\gamma$ (for ice surfaces) and absorption cross-sections $\sigma$ obtained from Sander et al. (2011).

\begin{tabular}{|c|c|c|c|c|c|c|c|c|c|}
\hline & \multicolumn{7}{|c|}{ Gas-phase reactions } & \multirow{2}{*}{$\frac{\text { A-factor }}{1.6 \times 10^{-11}}$} & \multirow{2}{*}{$\begin{array}{l}\mathrm{E} / \mathrm{R} \\
780\end{array}$} \\
\hline $\mathrm{R} 1$ & $\mathrm{Br}$ & + & $\mathrm{O}_{3}$ & $\longrightarrow$ & $\mathrm{BrO}$ & + & $\mathrm{O}_{2}$ & & \\
\hline $\mathrm{R} 2$ & $\mathrm{BrO}$ & + & $\mathrm{O}^{3} \mathrm{P}$ & $\longrightarrow$ & $\mathrm{Br}$ & + & $\mathrm{O}_{2}$ & $1.9 \times 10^{-11}$ & -230 \\
\hline R3 & $\mathrm{BrO}$ & + & NO & $\longrightarrow$ & $\mathrm{Br}$ & + & $\mathrm{NO}_{2}$ & $8.8 \times 10^{-12}$ & -260 \\
\hline R4 & $\mathrm{BrO}$ & + & $\mathrm{OH}$ & $\longrightarrow$ & $\mathrm{Br}$ & + & $\mathrm{HO}_{2}$ & $1.7 \times 10^{-11}$ & -250 \\
\hline R5 & $\mathrm{BrO}$ & + & $\mathrm{ClO}$ & $\longrightarrow$ & $\mathrm{Br}$ & + & $\mathrm{OClO}$ & $9.5 \times 10^{-13}$ & -550 \\
\hline R6 & $\mathrm{BrO}$ & + & $\mathrm{ClO}$ & $\longrightarrow$ & $\mathrm{Br}$ & + & $\mathrm{Cl}+\mathrm{O}_{2}$ & $2.3 \times 10^{-12}$ & -260 \\
\hline $\mathrm{R} 7$ & $\mathrm{BrO}$ & + & $\mathrm{BrO}$ & $\longrightarrow$ & $2 \mathrm{Br}$ & + & $\mathrm{O}_{2}$ & $1.5 \times 10^{-12}$ & -230 \\
\hline R8 & $\mathrm{BrO}$ & + & $\mathrm{ClO}$ & $\longrightarrow$ & $\mathrm{BrCl}$ & + & $\mathrm{O}_{2}$ & $4.1 \times 10^{-13}$ & -290 \\
\hline R9 & $\mathrm{BrO}$ & + & $\mathrm{NO}_{2}+M$ & $\longrightarrow$ & $\mathrm{BrONO}_{2}$ & + & $M$ & & \\
\hline $\mathrm{R} 10$ & $\mathrm{BrONO}_{2}$ & + & $\mathrm{O}^{3} \mathrm{P}$ & $\longrightarrow$ & $\mathrm{BrO}$ & + & $\mathrm{NO}_{3}$ & $1.9 \times 10^{-11}$ & -215 \\
\hline $\mathrm{R} 11$ & $\mathrm{HOBr}$ & + & $\mathrm{O}^{3} \mathrm{P}$ & $\longrightarrow$ & $\mathrm{BrO}$ & + & $\mathrm{OH}$ & $1.2 \times 10^{-10}$ & 430 \\
\hline $\mathrm{R} 12$ & $\mathrm{BrO}$ & + & $\mathrm{HO}_{2}$ & $\longrightarrow$ & $\mathrm{HOBr}$ & + & $\mathrm{O}_{2}$ & $4.5 \times 10^{-12}$ & -460 \\
\hline R13 & $\mathrm{BrO}$ & + & $\mathrm{OH}$ & $\longrightarrow$ & $\mathrm{HBr}$ & + & $\mathrm{O}_{2}$ & $1.7 \times 10^{-11}$ & -250 \\
\hline $\mathrm{R} 14$ & $\mathrm{Br}$ & + & $\mathrm{HCHO}$ & $\longrightarrow$ & $\mathrm{HBr}$ & + & $\mathrm{O}_{2}$ & $1.7 \times 10^{-11}$ & 800 \\
\hline $\mathrm{R} 15$ & $\mathrm{Br}$ & + & $\mathrm{HO}_{2}$ & $\longrightarrow$ & $\mathrm{HBr}$ & + & $\mathrm{O}_{2}$ & $4.8 \times 10^{-12}$ & 310 \\
\hline R16 & $\mathrm{HBr}$ & + & $\mathrm{OH}$ & $\longrightarrow$ & $\mathrm{Br}$ & + & $\mathrm{H}_{2} \mathrm{O}$ & $5.5 \times 10^{-12}$ & -200 \\
\hline $\mathrm{R} 17$ & $\mathrm{HBr}$ & + & $\mathrm{O}^{1} \mathrm{D}$ & $\longrightarrow$ & $\mathrm{Br}$ & + & $\mathrm{OH}$ & $1.5 \times 10^{-10}$ & 0 \\
\hline R18 & $\mathrm{HBr}$ & + & $\mathrm{O}^{3} \mathrm{P}$ & $\longrightarrow$ & $\mathrm{Br}$ & + & $\mathrm{OH}$ & $5.8 \times 10^{-12}$ & 1500 \\
\hline \multicolumn{8}{|c|}{ Heterogeneous reactions } & \multicolumn{2}{|l|}{$\gamma$} \\
\hline H1 & $\operatorname{HOBr}(\mathrm{g})$ & + & $\operatorname{HBr}(\mathrm{s})$ & $\longrightarrow$ & $2 \mathrm{Br}(\mathrm{g})$ & + & $\mathrm{H}_{2} \mathrm{O}(\mathrm{s})$ & \multicolumn{2}{|l|}{0.12} \\
\hline $\mathrm{H} 2$ & $\operatorname{HOBr}(\mathrm{g})$ & + & $\mathrm{HCl}(\mathrm{s})$ & $\longrightarrow$ & $\operatorname{BrCl}(\mathrm{g})$ & + & $\mathrm{H}_{2} \mathrm{O}(\mathrm{s})$ & \multicolumn{2}{|l|}{0.3} \\
\hline H3 & $\mathrm{HOCl}(\mathrm{g})$ & + & $\mathrm{HBr}(\mathrm{s})$ & $\longrightarrow$ & $\operatorname{BrCl}(\mathrm{g})$ & + & $\mathrm{H}_{2} \mathrm{O}(\mathrm{s})$ & \multicolumn{2}{|l|}{0.06} \\
\hline $\mathrm{H} 4$ & $\mathrm{BrONO}_{2}(\mathrm{~g})$ & + & $\mathrm{HBr}(\mathrm{s})$ & $\longrightarrow$ & $2 \mathrm{Br}(\mathrm{g})$ & + & $\mathrm{HNO}_{3}(\mathrm{~s})$ & \multicolumn{2}{|l|}{0.3} \\
\hline H5 & $\mathrm{BrONO}_{2}(\mathrm{~g})$ & + & $\mathrm{H}_{2} \mathrm{O}(\mathrm{s})$ & $\longrightarrow$ & $\operatorname{HOBr}(\mathrm{g})$ & + & $\mathrm{HNO}_{3}(\mathrm{~s})$ & \multicolumn{2}{|l|}{0.2} \\
\hline H6 & $\mathrm{BrONO}_{2}(\mathrm{~g})$ & + & $\mathrm{HCl}(\mathrm{s})$ & $\longrightarrow$ & $\operatorname{BrCl}(\mathrm{g})$ & + & $\mathrm{HNO}_{3}(\mathrm{~s})$ & \multicolumn{2}{|l|}{0.2} \\
\hline $\mathrm{H} 7$ & $\mathrm{ClONO}_{2}(\mathrm{~g})$ & + & $\operatorname{HBr}(\mathrm{s})$ & $\longrightarrow$ & $\mathrm{BrCl}(\mathrm{g})$ & + & $\mathrm{HNO}_{3}(\mathrm{~s})$ & \multicolumn{2}{|l|}{0.3} \\
\hline H8 & $\mathrm{N}_{2} \mathrm{O}_{5}(\mathrm{~g})$ & + & $\operatorname{HBr}(\mathrm{s})$ & $\longrightarrow$ & $\operatorname{Br}(\mathrm{g})$ & + & $\mathrm{NO}_{2}(\mathrm{~g})+\mathrm{HNO}_{3}(\mathrm{~s})$ & \multicolumn{2}{|c|}{$5 \times 10^{-3}$} \\
\hline \multicolumn{8}{|c|}{ Photolytic reactions } & \multicolumn{2}{|c|}{$\sigma$ parametrization } \\
\hline $\mathrm{P} 1$ & $\mathrm{BrO}$ & + & $h v$ & $\longrightarrow$ & $\mathrm{Br}$ & + & $\mathrm{O}^{3} \mathrm{P}$ & \multicolumn{2}{|c|}{ Gilles et al. (1997) } \\
\hline $\mathrm{P} 2$ & $\mathrm{HOBr}$ & + & $h v$ & $\longrightarrow$ & $\mathrm{Br}$ & + & $\mathrm{OH}$ & \multicolumn{2}{|c|}{ Ingham et al. (1998) } \\
\hline P3 & $\mathrm{HBr}$ & + & $h v$ & $\longrightarrow$ & $\mathrm{Br}$ & + & $\mathrm{H}$ & \multicolumn{2}{|c|}{ Nee et al. (1986) } \\
\hline $\mathrm{P} 4$ & $\mathrm{BrONO}_{2}$ & + & $h v$ & $\longrightarrow$ & $\mathrm{Br}$ & + & $\mathrm{NO}_{3}$ & \multicolumn{2}{|c|}{ Burkholder et al. (1995) } \\
\hline P5 & $\mathrm{BrCl}$ & + & $h v$ & $\longrightarrow$ & $\mathrm{Br}$ & + & $\mathrm{Cl}$ & \multicolumn{2}{|c|}{ Maric et al. (1994) } \\
\hline
\end{tabular}

\section{Model description}

The model used in this study is the isentropic Bremen 3-D CTM (B3DCTM) with 29 levels from 330 to $2700 \mathrm{~K}$ (about $10-55 \mathrm{~km}$ ) and a spatial resolution of $2.5^{\circ}$ lat. $\times 3.75^{\circ}$ lon. which has been used and evaluated in previous studies (e.g. Sinnhuber et al., 2003, 2011; Aschmann et al., 2009, 2011). Meteorological input is derived from the ERA-Interim (EI) reanalysis of the European Centre for Medium-Range Weather Forecasts (ECMWF; Dee et al., 2011). Large-scale vertical transport is calculated from diabatic heating rates, complemented by a fast and localized convective transport component based on convective detrainment rates. Both heating and detrainment rates are obtained from the EI data set. We demonstrated in Aschmann et al. (2009) that our vertical transport scheme is well suited for the TTL by comparing several key proxies related to vertical transport (e.g., convective turnover times, water vapor tape recorder phases, mixing ratios of short-lived tracers) to observational data and found generally good agreement.

The model incorporates a comprehensive chemistry scheme originally based on the chemistry part of the SLIMCAT model (Chipperfield, 1999). It was updated and extended for this work and includes 59 species and about 180 photochemical reactions. With respect to bromine species, it contains the major long-lived gases $\mathrm{CH}_{3} \mathrm{Br}, \mathrm{CBrClF}_{2}$ and $\mathrm{CBrF}_{3}$ together with the two most important VSLS, $\mathrm{CHBr}_{3}$ and $\mathrm{CH}_{2} \mathrm{Br}_{2}$. As the model does not explicitly contain the boundary layer and the free troposphere, assumptions about 
Table 2. Overview of conducted sensitivity calculations concentrating on bromine source gases and the corresponding source and product gas injection mixing ratios (in pptv) for 2006 (for the nomenclature of the runs, see Sect. 3.1). The parameters $j$ photolysis rate, $k$ rate constant, $d_{\mathrm{c}}$ convective detrainment rate, $\omega_{\mathrm{r}}$ radiative heating rate have been modified each by $\pm 50 \%$ (factors $1.5,0.5$ ) in the respective model run. The runs where a parameter is decreased are not listed here explicitly but their results are given in parentheses. For example, the SGI mixing ratio of $\mathrm{CHBr}_{3}$ where the photolysis rate of this species is increased by $50 \%$ is $1.52 \mathrm{pptv}$ (run $\mathrm{SC}_{\mathrm{c}}$ ). The corresponding run $\overline{\mathrm{SC}} 1_{\mathrm{c}}$ with the opposite effect, $50 \%$ reduction of $\mathrm{CHBr}_{3}$ photolysis, yields a value of 1.57 pptv. Entries containing the star symbol $\left(^{*}\right)$ are identical to the corresponding values of the reference simulations $\mathrm{SCO}_{\mathrm{a}-\mathrm{c}}$.

\begin{tabular}{lccccl}
\hline & \multicolumn{2}{c}{$\mathrm{CHBr}_{3}$} & \multicolumn{2}{c}{$\mathrm{CH}_{2} \mathrm{Br}_{2}$} & \\
Run & SGI & PGI & SGI & PGI & Description \\
\hline $\mathrm{SC}_{\mathrm{a}-\mathrm{c}}$ & 1.54 & 1.45 & 1.88 & 0.12 & Reference simulation \\
$\mathrm{SC} 1_{\mathrm{c}}$ & $1.52(1.57)$ & $1.48(1.43)$ & $*$ & $*$ & Increased $j$ for $\mathrm{CHBr}_{3}$ photolysis \\
$\mathrm{SC} 2_{\mathrm{c}}$ & $*$ & $*$ & $1.86(1.90)$ & $0.14(0.10)$ & Increased $j$ for $\mathrm{CH}_{2} \mathrm{Br}_{2}$ photolysis \\
$\mathrm{SC} 3_{\mathrm{c}}$ & $1.52(1.57)$ & $1.47(1.43)$ & $*$ & $*$ & Increased $k$ for $\mathrm{OH}$ reaction with $\mathrm{CHBr}_{3}$ \\
$\mathrm{SC} 4_{\mathrm{c}}$ & $*$ & $*$ & $1.85(1.90)$ & $0.15(0.10)$ & Increased $k$ for $\mathrm{OH}$ reaction $\mathrm{with}_{2} \mathrm{CH}_{2} \mathrm{Br}_{2}$ \\
$\mathrm{SC} 5_{\mathrm{a}-\mathrm{c}}$ & $1.57(1.49)$ & $1.43(1.50)$ & $1.88(1.87)$ & $0.12(0.13)$ & Increased $d_{\mathrm{c}}$ below 353 K \\
$\mathrm{SC} 6_{\mathrm{a}-\mathrm{c}}$ & $1.67(1.35)$ & $1.32(1.65)$ & $1.89(1.86)$ & $0.11(0.14)$ & Increased $d_{\mathrm{c}}$ above 353 K \\
$\mathrm{SC} 12_{\mathrm{a}-\mathrm{c}}$ & $1.64(1.37)$ & $1.36(1.66)$ & $1.90(1.84)$ & $0.10(0.13)$ & Increased $\omega_{\mathrm{r}}$ globally \\
\hline
\end{tabular}

the mixing ratio of source gases in this altitude region must be made in order to model convective exchange with the upper troposphere. This mixing ratio is essentially a free parameter in the model and is in the following referred to as detrainment mixing ratio (for details, see Aschmann et al., 2009). For the detrainment mixing ratio of long-lived source gases, we rely on climatological data such as WMO scenario A1 (Daniel and Velders, 2011). For the short-lived $\mathrm{CHBr}_{3}$ and $\mathrm{CH}_{2} \mathrm{Br}_{2}$, we simply assume a fixed and uniform detrainment mixing ratio of $1 \mathrm{pptv}$, which is consistent with the estimated tropical average of these species in the marine boundary layer (e.g. Montzka and Reimann, 2011). On the product gas side, the partitioning among the inorganic bromine family is explicitly calculated, comprising the species $\mathrm{Br}$, $\mathrm{BrO}, \mathrm{HBr}, \mathrm{HOBr}, \mathrm{BrONO}_{2}$ and $\mathrm{BrCl}$. Table 1 lists all included gas-phase, heterogeneous and photolytic reactions for bromine tracers along with the utilized kinetic data from the recent JPL recommendations (Sander et al., 2011).

The chemistry scheme contains an equilibrium treatment of liquid aerosols, nitric acid trihydrate and ice particles and is taken unchanged from Aschmann et al. (2011). For our study, we concentrate mainly on the heterogeneous chemistry on ice surfaces which is clearly dominating at the tropical tropopause as illustrated by Fig. 1. Over most of the TTL region the average reaction rates on ice exceed those on other particles surfaces by several orders of magnitude, only at the upmost levels of the upper troposphere/lower stratosphere (around $17 \mathrm{~km}$ altitude) does the relative importance of liquid aerosol reactions increase. A related and equally important aspect for this study is the uptake of inorganic bromine product gases on ice surfaces. According to the recent IUPAC recommendation only $\mathrm{HBr}$ is efficiently adsorbed on ice under atmospheric conditions (Crowley et al., 2010). The partitioning between gas-phase and surface adsorption can be

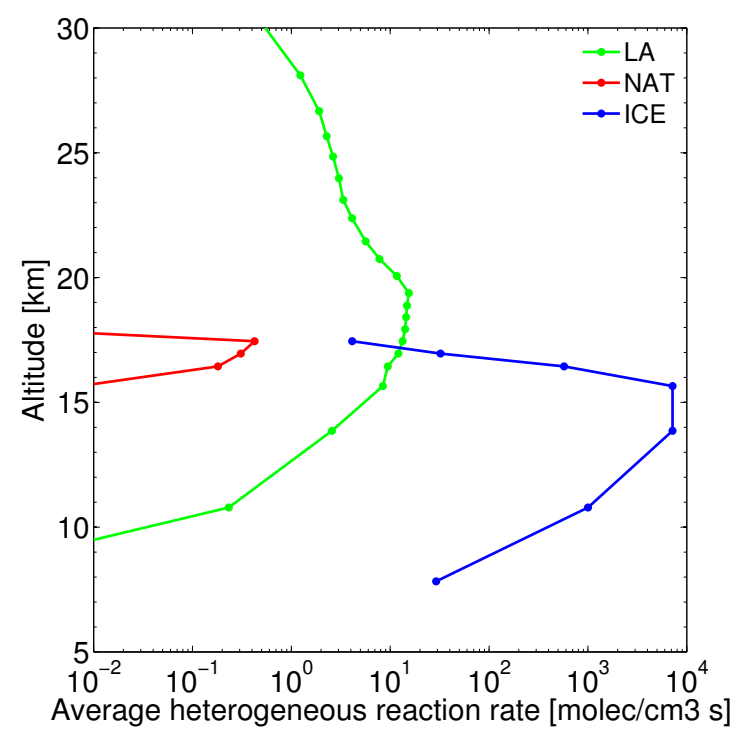

Fig. 1. Averaged tropical profiles $\left(20^{\circ} \mathrm{N}-20^{\circ} \mathrm{S}\right.$, June, 2006) of heterogeneous reaction rates on liquid aerosols (LA), nitric acid trihydrate (NAT) and ice particles (ICE) in the CTM. The corresponding reactions are listed in Table 1.

described by a quasi-Langmuir model:

$[\mathrm{HBr}]_{\mathrm{S}}=[\mathrm{HBr}]_{\mathrm{g}}^{0.88} \cdot K_{\mathrm{linC}} \cdot A$

Here, $K_{\text {linC }}$ denotes the partition coefficient for $\mathrm{HBr}$ on ice $\left(4.14 \times 10^{5} \mathrm{~cm}\right)$ and $A$ the available surface area density of the ice particles. In the model, $A$ is calculated from the effective particle radius which is approximated from the total ice volume in a particular grid box and an assumed number density of ice particles of $10 \mathrm{~cm}^{-3}$. Particles and adsorbed species sediment with a prescribed fall velocity (Sect. 3.4.2). 
Table 3. Overview of conducted dehydration-related sensitivity calculations together with the tropical averaged mixing ratio of $\mathrm{Br}_{\mathrm{y}}$ at $380 \mathrm{~K}$ (in pptv) for 2006. Values in parentheses denote the sensitivity calculations where the opposite effect was applied (compare Table 2). Entries containing the star symbol $\left({ }^{*}\right)$ are identical to the corresponding values of the reference simulations $\mathrm{SC}_{\mathrm{a}-\mathrm{c}}$.

\begin{tabular}{lcl}
\hline Run & $\mathrm{Br}_{\mathrm{y}} @ 380 \mathrm{~K}$ & Description \\
\hline $\mathrm{SC} 0_{\mathrm{a}-\mathrm{c}}$ & 1.83 & Reference simulation \\
$\mathrm{SC} 7_{\mathrm{c}}$ & 1.37 & No heterogeneous chemistry \\
$\mathrm{SC} 10_{\mathrm{c}}$ & $1.38(1.37)$ & No het. chem., temperature increased by $2 \mathrm{~K}$ \\
$\mathrm{SC} 11_{\mathrm{c}}$ & $1.32(1.45)$ & No het. chem., sedimentation velocity increased by $50 \%$ \\
$\mathrm{SC} 13_{\mathrm{c}}$ & $1.30(1.50)$ & No het. chem., $K_{\text {linC }}$ for $\mathrm{HBr}$ increased by $50 \%$ \\
$\mathrm{SC} 14_{\mathrm{c}}$ & 0.60 & Instantaneous removal of adsorbed species \\
$\mathrm{SC} 15_{\mathrm{c}}$ & 0.43 & No het. chem., instantaneous removal of adsorbed species \\
$\mathrm{SC} 16_{\mathrm{c}}$ & 1.25 & HOBr adsorbed on ice the same way as $\mathrm{HBr}$ \\
$\mathrm{SC} 17_{\mathrm{c}}$ & $*$ & HBr yield of reaction R12 set to $0.1 \%$ \\
$\mathrm{SC} 19_{\mathrm{c}}$ & $*$ & $\gamma$ increased by $50 \%$ for reactions $\mathrm{H} 1, \mathrm{H} 3, \mathrm{H} 7$ \\
$\mathrm{SC} 23_{\mathrm{c}}$ & 1.32 & No het. chem., HOBr adsorbed on ice the same way as $\mathrm{HBr}$ \\
\hline
\end{tabular}

We conduct a number of sensitivity calculations where we changed certain aspects of the model. The sensitivity runs are described in detail in the corresponding sections (Sects. 3.3 and 3.4), for an overview refer to Tables 2 and 3. All runs started in 2004 from a $25-y r$ reference simulation with the same model and are integrated until the end of 2006. Only the last year is used for analysis, the rest discarded as spinup. We picked the year 2006 for our analysis because it is relatively unaffected by the El Niño Southern Oscillation (ENSO) that would otherwise strongly influence the transport of short-lived substances (e.g. Aschmann et al., 2011; Ashfold et al., 2012).

\section{Results}

A basic analysis of the relative importance of source and product gas injection of bromine VSLS is performed using a set of reference simulations with our unperturbed standard model (Sect. 3.2). We then use sensitivity calculations to investigate the associated processes in more detail: Section 3.3 concentrates on factors controlling SGI of bromine VSLS whereas Sect. 3.4 focuses on the impact of dehydration on inorganic bromine in the TTL.

\subsection{Definitions}

In this study, the fraction of SGI and PGI of VSLS is estimated from the amount of source and product gases at the top of the tropical tropopause ("cold point tropopause"), which is assumed here to be located at $380 \mathrm{~K}$ or about $17 \mathrm{~km}$ altitude. Since neither dehydration of tropospheric air nor deep convection plays a significant role above this altitude (e.g. Dessler, 2002; Fueglistaler et al., 2009), it is justified to perform the distinction between SGI and PGI here. Source gas injection of both VSLS can be directly obtained from the mixing ratios of the corresponding species at $380 \mathrm{~K}$ from a simulation which includes these species. For convenience,

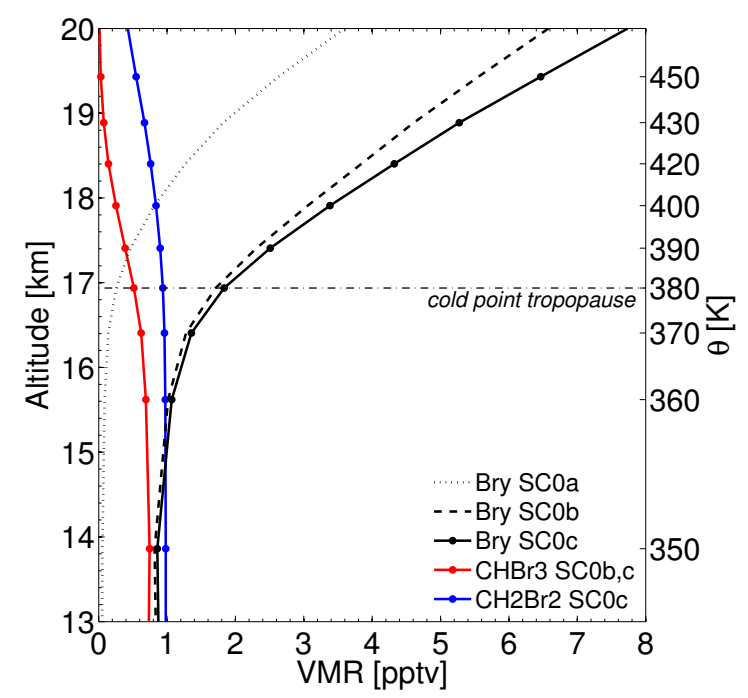

Fig. 2. Averaged tropical profiles $\left(20^{\circ} \mathrm{N}-20^{\circ} \mathrm{S}, 2006\right)$ of inorganic bromine $\left(\mathrm{Br}_{\mathrm{y}}\right), \mathrm{CHBr}_{3}$ and $\mathrm{CH}_{2} \mathrm{Br}_{2}$ from the reference simulation runs $\mathrm{SCO}_{\mathrm{a}-\mathrm{c}}$.

the SGI mixing ratios are multiplied with a factor corresponding to the number of bromine atoms in the source gas molecule $\left(\times 3\right.$ for $\mathrm{CHBr}_{3}, \times 2$ for $\left.\mathrm{CH}_{2} \mathrm{Br}_{2}\right)$ to ensure direct comparability with the PGI mixing ratios. To determine the product gas injection of $\mathrm{CHBr}_{3}$ against the background of the ubiquitous long-lived bromine source gases we use the difference of $\mathrm{Br}_{\mathrm{y}}$ mixing ratios at $380 \mathrm{~K}$ between a run with additional $\mathrm{CHBr}_{3}$ included and a run with only long-lived source gases. Likewise, PGI of $\mathrm{CH}_{2} \mathrm{Br}_{2}$ is calculated using the difference in $\mathrm{Br}_{\mathrm{y}}$ mixing ratios between the former run with additional $\mathrm{CHBr}_{3}$ and a simulation where both $\mathrm{CHBr}_{3}$ and $\mathrm{CH}_{2} \mathrm{Br}_{2}$ are included. Therefore, we generally have three variants of a single model experiment, each denoted by a suffix: for example, the reference simulation contains three runs, $\mathrm{SCO}_{\mathrm{a}}, \mathrm{SCO}_{\mathrm{b}}$ and $\mathrm{SCO}_{\mathrm{c}}$; where (a) denotes a run with only 


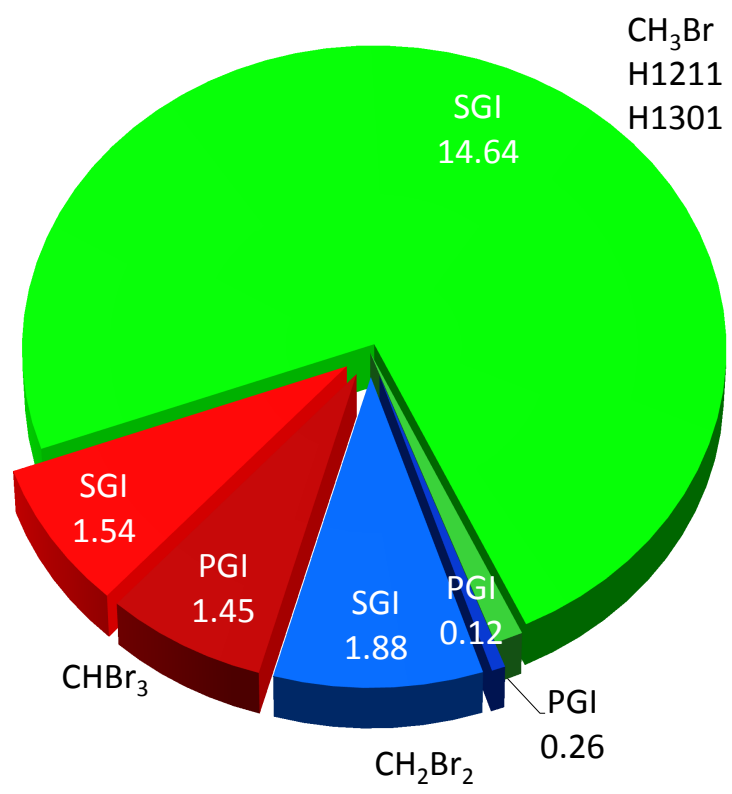

Fig. 3. Average tropical source and product gas injection (SGI/PGI) for bromine long-lived source gases $\left(\mathrm{CH}_{3} \mathrm{Br}, \mathrm{H} 1211, \mathrm{H} 1301\right)$ and VSLS $\left(\mathrm{CHBr}_{3}\right.$ and $\left.\mathrm{CH}_{2} \mathrm{Br}_{2}\right)$ in the reference simulation run $\mathrm{SCO}_{\mathrm{c}}$ for 2006 in pptv.

long-lived bromine source gases, (b) a run with additional $\mathrm{CHBr}_{3}$ and (c) a run with both $\mathrm{CHBr}_{3}$ and $\mathrm{CH}_{2} \mathrm{Br}_{2}$ included (e.g. Fig. 2). In practice, only the (c) variant exists for several model experiments, as the limited changes in the particular run allows the reuse of the reference simulations $\mathrm{SCO}_{\mathrm{a}} / \mathrm{SCO}_{\mathrm{b}}$ to calculate the corresponding PGI (Table 2). Unless noted otherwise, the given mixing ratios in this paper are tropical means, i.e. zonal and meridional averages in the range of $20^{\circ} \mathrm{N}-20^{\circ} \mathrm{S}$.

\subsection{Reference simulation}

The unperturbed state of the model is described by the reference simulation runs $\mathrm{SCO}_{\mathrm{a}-\mathrm{c}}$. Figure 2 shows the averaged tropical profiles $\left(20^{\circ} \mathrm{N}-20^{\circ} \mathrm{S}\right)$ for the corresponding $\mathrm{Br}_{\mathrm{y}}$ profiles obtained from calculations without any VSLS, only $\mathrm{CHBr}_{3}$ and with $\mathrm{CHBr}_{3}$ and $\mathrm{CH}_{2} \mathrm{Br}_{2}$ included $\left(\mathrm{SCO}_{\mathrm{a}}\right.$, $\mathrm{SC}_{\mathrm{b}}$ and $\mathrm{SC}_{\mathrm{c}}$, respectively) in 2006. The resulting fraction of source and product gas injection of bromine source gases, calculated as described in Sect. 3.1, is illustrated in Fig. 3. Obviously, $\mathrm{Br}_{\mathrm{y}}$ below $17 \mathrm{~km}$ is dominated by shortlived source gases since only a minor fraction of the combined long-lived source gases $\left(\mathrm{CH}_{3} \mathrm{Br}, \mathrm{CBrClF}_{2}, \mathrm{CBrF}_{3}\right)$ decays below the cold point $(\approx 2 \%)$. This is not surprising considering the typical photochemical lifetime of these species in the troposphere, which is in the case of the anthropogenic halons Halon-1211 and Halon-1301 in the range of decades (16 and 65 yr, respectively; Montzka and Reimann, 2011). In fact, the small amount of $\mathrm{Br}_{\mathrm{y}}$ in run $\mathrm{SCO}_{\mathrm{a}}$ at the tropopause is likely originated from the considerably shorter-lived $\mathrm{CH}_{3} \mathrm{Br}$, having a typical lifetime of about nine months. More interesting is the prominent role of SGI also for the shortlived source gases: the troposphere-stratosphere exchange of $\mathrm{CH}_{2} \mathrm{Br}_{2}$ is clearly dominated by SGI $(94 \%)$, and even for the shorter-lived $\mathrm{CHBr}_{3}$ more than half of this species reaches the stratosphere intact (52\%). Note that the sum of SGI and PGI for $\mathrm{CHBr}_{3}$ with 2.998 pptv (not rounded) is slightly lower than the expected 3 pptv, considering the assumed detrainment mixing ratio of $1 \mathrm{pptv}$ for $\mathrm{CHBr}_{3}$. This discrepancy represents the negligible effect of dehydration at the tropopause on inorganic bromine as discussed in Aschmann et al. (2011). This phenomena will be investigated in more detail in Sect. 3.4.

Source and product gas injection is obviously directly coupled to vertical transport and thus variable over time. Figure 4 illustrates this variability for the reference simulation and shows the tropical mean SGI mixing ratios for $\mathrm{CHBr}_{3}$ and $\mathrm{CH}_{2} \mathrm{Br}_{2}$ along with the primary drivers of vertical transport in the model, the diabatic radiative heating rate and the convective detrainment rate, averaged in the vertical range above the LZRH up to the cold point. The importance of SGI for VSLS is significantly correlated to these proxies (correlation VSLS vs. heating/detrainment rate: $r=0.67,0.59$ for $\mathrm{CHBr}_{3} ; r=0.42,0.44$ for $\mathrm{CH}_{2} \mathrm{Br}_{2}$ ), although the correlation coefficients and the amplitude is larger for the shorter-lived $\mathrm{CHBr}_{3}$. The relative fraction of SGI for the latter species varies in the range of $40-60 \%$. In case of $\mathrm{CH}_{2} \mathrm{Br}_{2}$ the relative fraction shows little variation (92-95\%), as this tracer is less dependent on rapid vertical transport in order to reach the stratosphere due to its longer lifetime.

\subsection{Impact of chemistry and vertical transport on VSLS source gas injection}

To identify the determining factors that control source and product gas injection of bromine VSLS we have conducted a set of sensitivity calculations for comparison with the reference simulation SC0. As shown in Table 2, a single parameter has been altered in each run: the first four sensitivity calculations concentrate on the photochemical degradation of the short-lived source gases. In run $\mathrm{SC}_{\mathrm{c}}$ and $\mathrm{SC}_{\mathrm{c}}$, the loss rate due to photolysis and hydroxyl radical reaction is modified by $50 \%$ (i.e. factor 1.5) for $\mathrm{CHBr}_{3}$, respectively. The same applies for $\mathrm{CH}_{2} \mathrm{Br}_{2}$ in the runs $\mathrm{SC}_{\mathrm{c}}$ and $\mathrm{SC}_{\mathrm{c}}$. The second part of the sensitivity calculations deals with the vertical transport. Run $\mathrm{SC} 5_{\mathrm{c}}$ changes the detrainment rate $d_{\mathrm{c}}$ below $353 \mathrm{~K}(\approx 14 \mathrm{~km})$ by $50 \%$, i.e. below the mean level of zero radiative heating whereas run $\mathrm{SC}_{\mathrm{c}}$ does the same above this layer $\left(>353 \mathrm{~K}\right.$ ). Finally, run $\mathrm{SC} 12_{\mathrm{c}}$ globally alters the diabatic radiative heating rate $\omega_{\mathrm{r}}$ by $50 \%$ over the entire altitude range. Note that for every described sensitivity calculation we also conducted a second run with an opposite change of parameter (i.e. factor 0.5 ; denoted as $\overline{\mathrm{SC} n}$ in contrast to $\mathrm{SC} n$, with run number $n$ ) in order to explicitly explore the parameter space in both directions. 


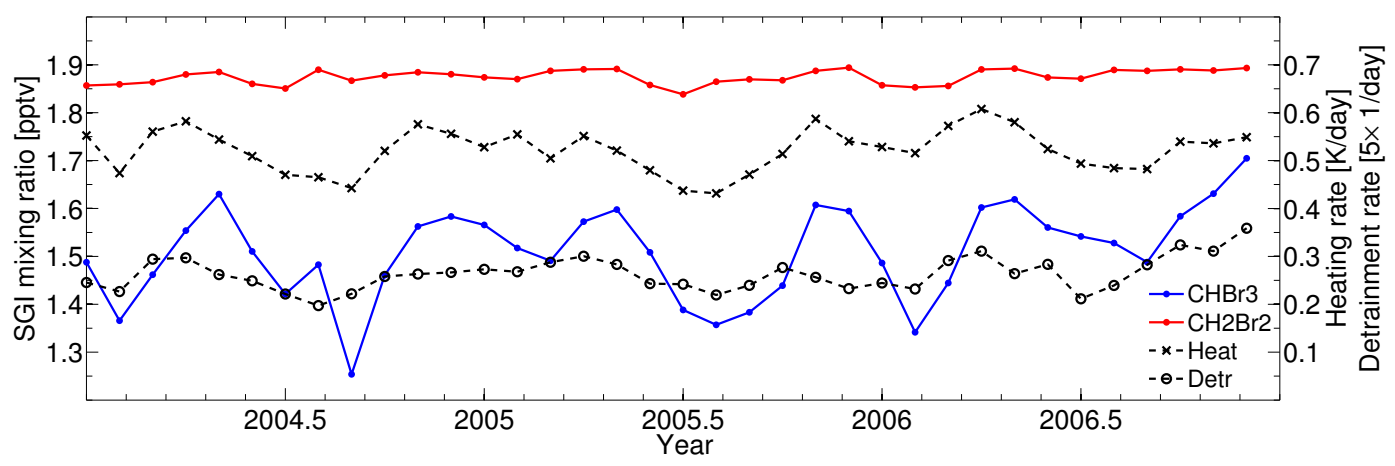

Fig. 4. Averaged tropical source gas injection of $\mathrm{CHBr}_{3}$ and $\mathrm{CH}_{2} \mathrm{Br}_{2}$ (blue and red, left ordinate; given in pptv of contributed bromine) obtained from reference simulations $\mathrm{SCO}_{\mathrm{a}-\mathrm{c}}$ together with ECMWF ERA-Interim radiative heating and convective detrainment rate (dashed, right ordinate). Note that the values for heating and detrainment rate are averages of the TTL region between 350 and $380 \mathrm{~K}$, i.e. the upper tropopause layer above the LZRH up to the cold point. The detrainment rate is also scaled by a factor of five.

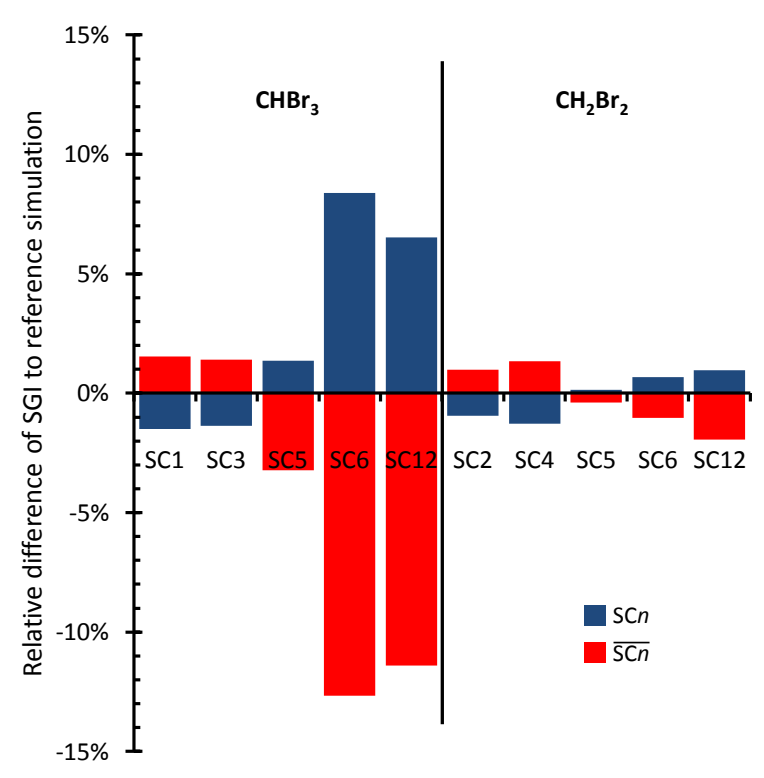

Fig. 5. Relative difference of tropical source gas injection mixing ratios of $\mathrm{CHBr}_{3}$ and $\mathrm{CH}_{2} \mathrm{Br}_{2}$ between sensitivity calculations $\mathrm{SCn}$ and reference simulation SC0 for 2006. The blue and red bars denote sensitivity runs where the same parameter is modified in opposite directions ( $\mathrm{SCn}$ and $\overline{\mathrm{SC} n}$, see also Table 2).

The resulting absolute values for SGI and PGI of bromine VSLS can be found in Table 2. More illustrative are the relative differences introduced by the parameter changes in relation to the reference simulation, i.e. $\left(\mathrm{SGI}_{\mathrm{SC} n}-\mathrm{SGI}_{\mathrm{SC} 0}\right) / \mathrm{SGI}_{\mathrm{SC} 0}$ with sensitivity run number $n$, as presented in Fig. 5 for source gas injection. The first interesting point is the small impact of photochemistry on the amount of short-lived source gases at the tropopause. SGI mixing ratios of both $\mathrm{CHBr}_{3}$ and $\mathrm{CH}_{2} \mathrm{Br}_{2}$ hardly change ( $2 \%$ at most) despite the relatively large modification of the photolysis/OH-reaction rate $( \pm 50 \%)$ in the runs $\mathrm{SC} 1$ 4. In contrast, the perturbation is considerably larger in the simulations with altered vertical transport, at least for $\mathrm{CHBr}_{3}$. A $50 \%$ increase in detrainment below $353 \mathrm{~K}$ does not change the amount of $\mathrm{CHBr}_{3}$ reaching the stratosphere significantly $(\approx 1 \%)$, as the majority of air detraining below the LZRH tends to subside again. The residual effect is most likely caused by the vertical variations of the LZRH which, for example, shows an annual cycle (e.g. Bergman et al., 2012). However, SGI of $\mathrm{CHBr}_{3}$ shows a stronger response to increased detrainment above the LZRH $(8 \%)$ and the overall vertical ascent diagnosed by diabatic heating rates $(6 \%)$. There is clear evidence that the interplay between localized deep convection and large-scale vertical transport is the primary controlling factor for the injection of short-lived source gases into the stratosphere. An interesting fact to note is the more pronounced response to a decrease of the aforementioned parameters in the contrary runs $\left(\overline{\mathrm{SC} 5}, \overline{\mathrm{SC} 6_{\mathrm{c}}}, \overline{\mathrm{SC} 12_{\mathrm{c}}}\right)$. Here, the relative differences are larger $(-3 \%,-13 \%,-12 \%$, respectively) compared to their positive counterparts which is most likely caused by a "saturation" effect of VSLS abundance in the TTL region. Apparently this model region is well-mixed even for VSLS up to an extent that any further increase in convective activity or diabatic transport will not increase their mixing ratios much further. In principle, the same applies also for $\mathrm{CH}_{2} \mathrm{Br}_{2}$, however the absolute and relative effect is much smaller. Actually this is not surprising, given the comparatively long photochemical lifetime of this species which makes it more independent from rapid vertical transport. In fact, SGI of $\mathrm{CH}_{2} \mathrm{Br}_{2}$ shows the strongest response to the modification of radiative heating $(+1 \%,-2 \%)$, i.e. the slow large-scale transport.

\subsection{Impact of dehydration on inorganic bromine}

Most previous studies assumed that the dehydration of the TTL represents an effective process to remove $\mathrm{Br}_{\mathrm{y}}^{\mathrm{VSLS}}$ by scavenging (e.g. Dvortsov et al., 1999; Nielsen and Douglass, 2001; Warwick et al., 2006; Hossaini et al., 2010; Schofield et al., 2011). However, there is some observational evidence 


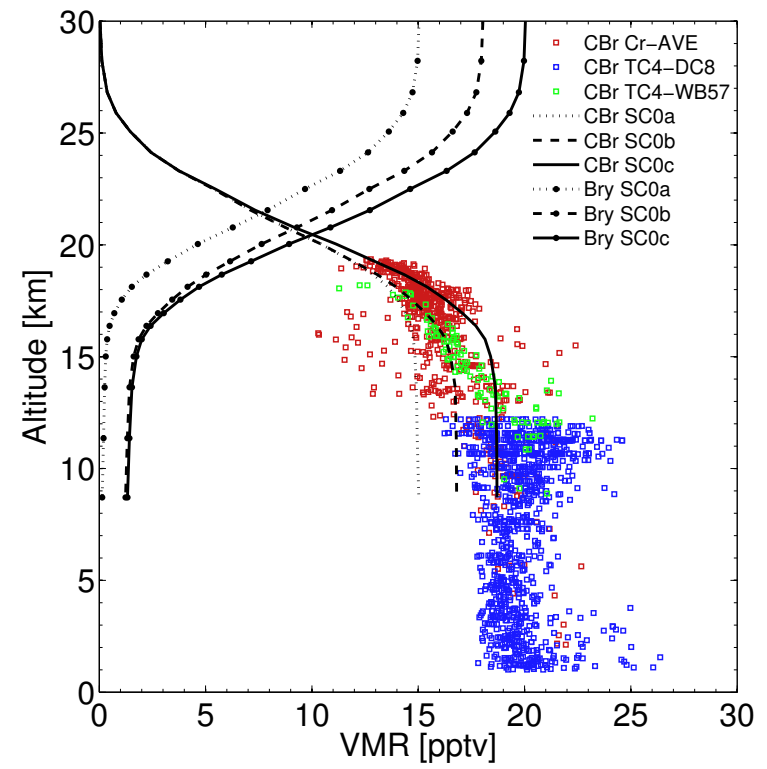

Fig. 6. Organic bromine source gases $(\mathrm{CBr})$ including $\mathrm{CBrClF}_{2}$, $\mathrm{CBrF}_{3}, \mathrm{CH}_{3} \mathrm{Br}, \mathrm{CHBr}_{3}$ and $\mathrm{CH}_{2} \mathrm{Br}_{2}$ from aircraft observations $\mathrm{Cr}$ AVE (Kroon et al., 2008) and TC4 (Toon et al., 2010) in compari-

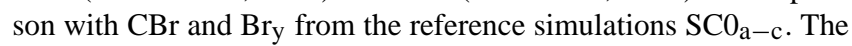
model data is a yearly average of 2006 for the observation area $\left(60^{\circ}-130^{\circ} \mathrm{W} ; 40^{\circ} \mathrm{N}-10^{\circ} \mathrm{S}\right)$. Adapted from Salawitch et al. $(2010$, auxiliary material).

that VSLS are fully contributing to stratospheric bromine loading. Salawitch et al. (2010) deduced a significant contribution of VSLS to stratospheric bromine in the range of 510 pptv by comparing $\mathrm{BrO}$ observations from multiple platforms in the Arctic. Considering the current estimates of VSLS mixing ratios in the boundary layer (1.6 and $1.1 \mathrm{pptv}$ for the most abundant species, $\mathrm{CHBr}_{3}$ and $\mathrm{CH}_{2} \mathrm{Br}_{2}$, respectively; Montzka and Reimann, 2011), this means a dominant part of the available bromine from VSLS is able to reach the stratosphere. This is consistent with our findings: Fig. 6 presents observations of organic bromine source gases $(\mathrm{CBr})$ including $\mathrm{CBrClF}_{2}, \mathrm{CBrF}_{3}, \mathrm{CH}_{3} \mathrm{Br}, \mathrm{CHBr}_{3}$ and $\mathrm{CH}_{2} \mathrm{Br}_{2}$ from aircraft observations Cr-AVE (Kroon et al., 2008) and TC4 (Toon et al., 2010) together with the corresponding values for the reference simulations $\mathrm{SCO}_{\mathrm{a}-\mathrm{c}}$, similarly to Salawitch et al. (2010). We generally achieve good agreement with the observational data for the run $\mathrm{SC}_{\mathrm{c}}$ with additional $5 \mathrm{pptv}$ from VSLS ( $\mathrm{CHBr}_{3}$ and $\mathrm{CH}_{2} \mathrm{Br}_{2}$ ), summing up to a total of about 20 pptv of $\mathrm{CBr}$ in the troposphere. The interesting point here is that the associated $\mathrm{Br}_{\mathrm{y}}$ profile of run $\mathrm{SCO}_{\mathrm{c}}$ also reaches $20 \mathrm{pptv}$ at an altitude where all organic source gases are degraded (around $30 \mathrm{~km}$ ), i.e. the VSLS contribute completely to stratospheric bromine thus ruling out dehydration as an efficient loss process for bromine. This is fully consistent with the recent estimations of stratospheric inorganic bromine of 19.5-24.5 pptv (Montzka and Reimann, 2011). In fact our $\mathrm{Br}_{\mathrm{y}}$ mixing ratio is rather at the lower end as we do not include some minor bromine source gases in the model, for example Halon-2402 (average boundary layer mixing ratio of $\approx 0.5 \mathrm{pptv}$ ) and the VSLS $\mathrm{CH}_{2} \mathrm{BrCl}, \mathrm{CHBr}_{2} \mathrm{Cl}, \mathrm{CHBrCl}_{2}$ (totaling $\approx 1.1$ pptv; Montzka and Reimann, 2011). However, as these species are sufficiently long-lived in the troposphere with average lifetimes of 20 years for Halon-2402 and 150, 69 and 78 days for the VSLS, respectively, one can safely assume that they would fully contribute to stratospheric bromine loading in the model. The resulting mixing ratio of stratospheric $\mathrm{Br}_{\mathrm{y}}$ would be then around 22 pptv and therefore perfectly match the WMO estimate.

We came to a similar conclusion regarding the ineffectiveness of dehydration as a loss process for $\mathrm{Br}_{\mathrm{y}}^{\mathrm{VSLS}}$ in our previous study with a similar model setup (Aschmann et al., 2011). The main reasons we found were on the one hand the effectiveness of heterogeneous reactions in converting potentially soluble bromine reservoir species to insoluble reactive species, on the other hand the adsorption of $\mathrm{Br}_{\mathrm{y}}$ on falling ice particles was found to be not very efficient, even if one ignores heterogeneous chemistry. In this study, we investigate the associated processes in more detail and test the robustness of our previous findings. Section 3.4.1 examines the partitioning of inorganic bromine in the TTL whereas Sect. 3.4.2 analyzes the efficiency of the adsorption process itself.

\subsubsection{Partitioning of inorganic bromine}

The partitioning among the inorganic bromine species in the TTL region between the LZRH and the cold point is a crucial factor determining the loss of $\mathrm{Br}_{\mathrm{y}}$ due to dehydration given the fact that only certain species among the $\mathrm{Br}_{\mathrm{y}}$ family can be scavenged by falling droplets or particles. $\mathrm{HBr}, \mathrm{HOBr}$ and $\mathrm{BrONO}_{2}$ are generally thought to be highly soluble in liquid water (e.g. Law and Sturges, 2007), however, the situation for ice, the most likely phase of water in the extraordinary cold TTL, is much more uncertain. According to Crowley et al. (2010), currently only $\mathrm{HBr}$ is considered to be efficiently adsorbed on ice particles, thus the fraction of $\mathrm{HBr}$ to $\mathrm{Br}_{\mathrm{y}}$ is an important factor for the loss of bromine due to dehydration.

The partitioning of $\mathrm{Br}_{\mathrm{y}}$ at the TTL is the result of a complex interplay of gas-phase, photolytic and heterogeneous reactions. Table 1 lists the associated reactions in the model whereas Fig. 7 provides an overview along with typical mixing ratios/number densities of the involved species together with typical reaction rates during day and night in the TTL at $362 \mathrm{~K}(15.5 \mathrm{~km})$, i.e. within the altitude range where dehydration is most relevant. At this height and under sunlit conditions (panel a), there is approximately $1.1 \mathrm{pptv}$ of $\mathrm{Br}_{\mathrm{y}}$ available, provided mainly by the decay of $\mathrm{CHBr}_{3}$ $(80 \%) .0 .8 \mathrm{pptv}$ can be allotted to the reactive species $\mathrm{BrO}$ (0.29 pptv) and $\mathrm{Br}(0.5 \mathrm{pptv})$, the rest to the reservoir species $\mathrm{HBr}$ and $\mathrm{HOBr}(0.16$ and 0.15 pptv, respectively). $\mathrm{BrCl}$ and $\mathrm{BrONO}_{2}$ are only available in insignificant amounts due to rapid photolysis. The most prominent feature of the $\mathrm{Br}_{\mathrm{y}}$ 

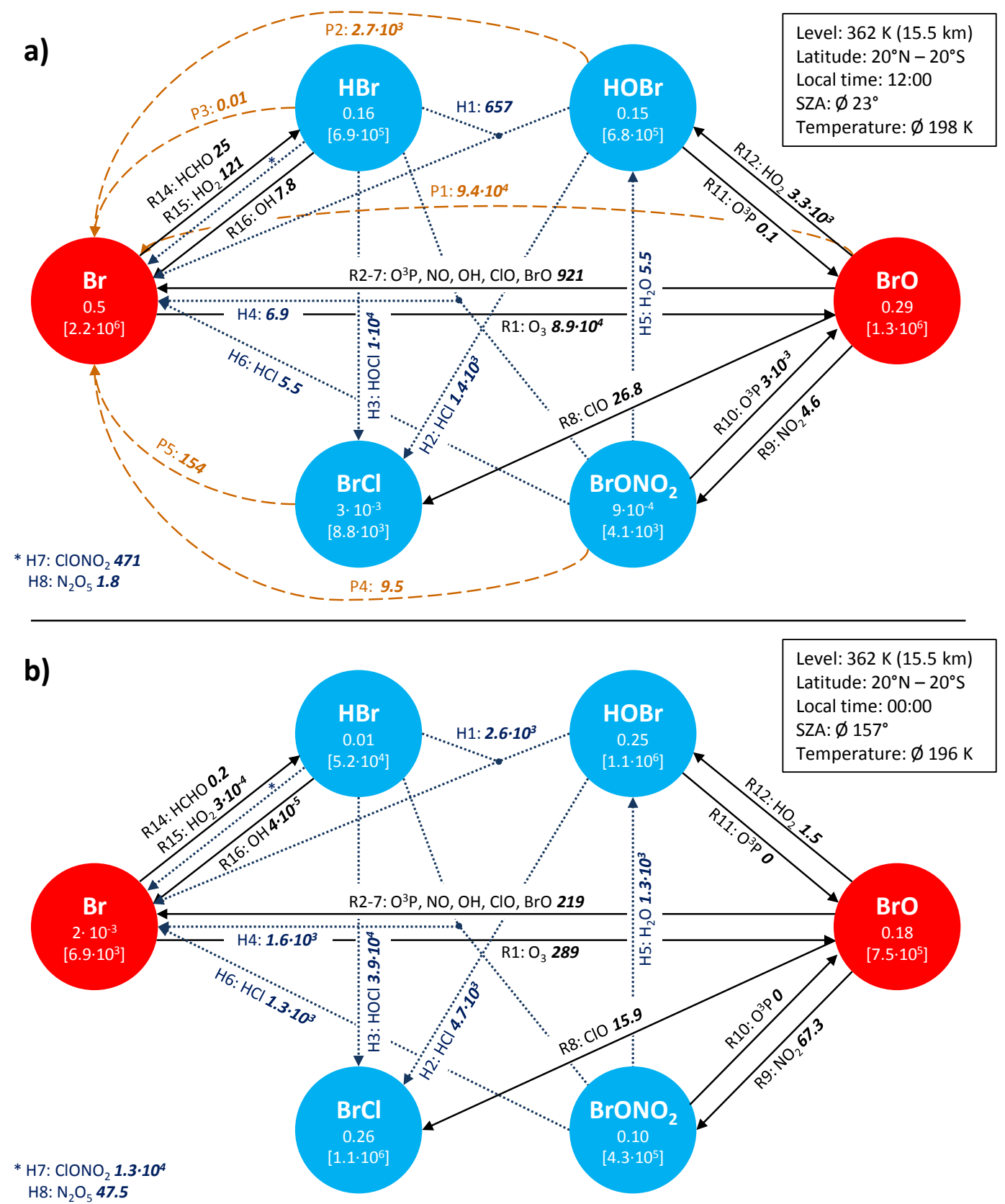

Fig. 7. Overview of $\mathrm{Br}_{\mathrm{y}}$ chemistry in the TTL. Gas-phase, photolytic and heterogeneous reactions are denoted by solid, dashed and dotted lines, respectively. The numbers represent a snapshot of reaction rates and tracer concentrations at $362 \mathrm{~K}$ in the tropics either under sunlit (upper panel) or nighttime conditions (lower panel) obtained from reference simulation SC0c (June, 2006). The values in the tracer circles are volume mixing ratio in pptv and number density in molec $\mathrm{cm}^{-3}$. Each reaction is labeled with the reaction number (see Table 1), a possible additional reactant and the reaction rate in $m o l e c \mathrm{~cm}^{-3} \mathrm{~s}^{-1}$.

photochemistry at this particular altitude is the rapid interconversion between $\mathrm{Br}$ and $\mathrm{BrO}$, driven mainly by the photolysis of $\mathrm{BrO}(\mathrm{P} 1)$ and the reaction of $\mathrm{Br}$ with $\mathrm{O}_{3}(\mathrm{R} 1)$. $\mathrm{BrO}$ also reacts rapidly with $\mathrm{HO}_{2}$ forming $\mathrm{HOBr}$, balanced by the efficient photolytic destruction of the latter species (P2) which in turn leads again to $\mathrm{Br}$. $\mathrm{HBr}$ is efficiently formed by the reactions of $\mathrm{Br}$ with $\mathrm{HCHO}$ and $\mathrm{HO}_{2}$, clearly outweigh- ing the loss via photolysis and $\mathrm{OH}$ reaction. Actually, the fraction of $\mathrm{HBr}$ to $\mathrm{Br}_{\mathrm{y}}$ would exceed $50 \%$ if only the photochemistry would be taken into account (Fig. 8). However, heterogeneous reactions on ice particle surfaces represent a very efficient conversion mechanism for bromine reservoir species. Although the conditions that allow the formation of ice particles are rarely matched, relative to the scale of the 


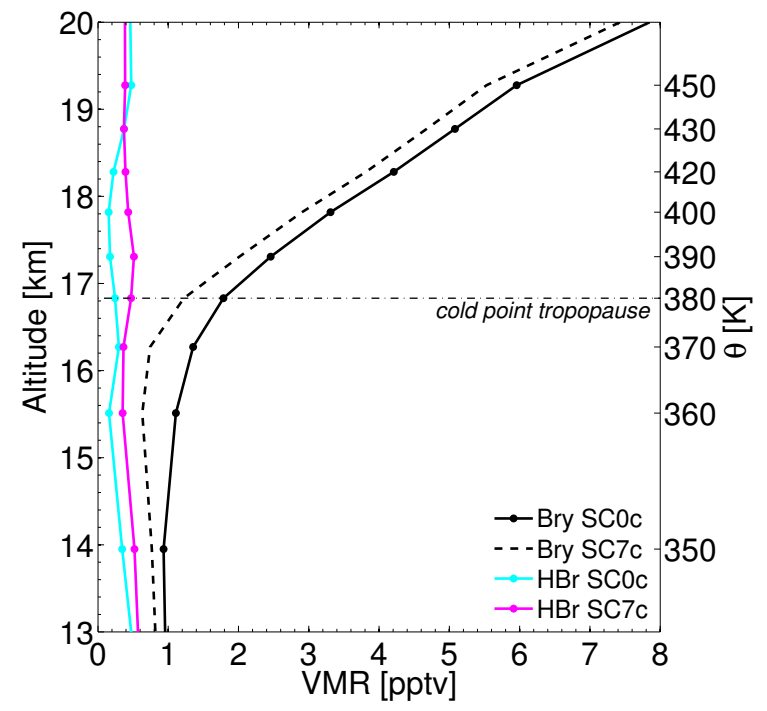

Fig. 8. Averaged tropical profiles $\left(20^{\circ} \mathrm{N}-20^{\circ} \mathrm{S}\right)$ of $\mathrm{Br}_{\mathrm{y}}$ and $\mathrm{HBr}$ from reference simulation $\mathrm{SC}_{\mathrm{c}}$ and the sensitivity calculation without heterogeneous reactions $\mathrm{SC}_{\mathrm{c}}$ for June 2006, 12:00 local time.

whole TTL, the conversion rates of the heterogeneous reactions are so large that they are able to significantly alter the tropical $\mathrm{Br}_{\mathrm{y}}$ partitioning (Figs. 1, 7). The most important reactions $(\mathrm{H} 2, \mathrm{H} 3)$ link $\mathrm{HBr}$ and $\mathrm{HOBr}$ to their chlorine counterparts ( $\mathrm{HOCl}$ and $\mathrm{HCl}$, respectively), leading both to the formation of $\mathrm{BrCl}$ which is quickly photolyzed to $\mathrm{Br}(\mathrm{P} 5)$. Also efficient are the reactions of $\mathrm{HBr}$ with $\mathrm{HOBr}(\mathrm{H} 1)$ and with $\mathrm{ClONO}_{2}(\mathrm{H} 7)$.

During nighttime, the mixing ratio of $\mathrm{Br}_{\mathrm{y}}$ is lower, about $0.8 \mathrm{pptv}$, as there is no substantial destruction of organic source gases that balances the continued inflow of $\mathrm{Br}_{\mathrm{y}}$-free air provided by convection. The concentration of $\mathrm{Br}$ drops drastically due to the absence of photolytic production and also the amount of $\mathrm{BrO}$ is roughly halved, leaving most inorganic bromine in the form of reservoir species. Heterogeneous reactions play again an important role in controlling the partitioning among the reservoir species: due to the lack of dissociating radiation and the abundance of chlorine compounds $\mathrm{BrCl}$ becomes the largest reservoir with $0.26 \mathrm{pptv}$, closely followed by $\mathrm{HOBr}(0.25 \mathrm{pptv})$. The concentrations of $\mathrm{BrONO}_{2}$ and especially $\mathrm{HBr}$ are lower $(0.1$ and $0.01 \mathrm{pptv}$, respectively), as there are efficient heterogeneous reactions present that rapidly convert these species.

To isolate the effect of heterogeneous chemistry, we first conducted a sensitivity calculation without any heterogeneous chemistry included ( $\mathrm{SC}_{\mathrm{c}}$, Table 3 ), similarly to Aschmann et al. (2011). The omission of these efficient conversion reactions thoroughly changes the $\mathrm{Br}_{\mathrm{y}}$ partitioning: given the same conditions as presented in Fig. 7 for reference run $\mathrm{SCO}_{\mathrm{c}}$, the mixing ratio of $\mathrm{HBr}$ reaches $0.35 \mathrm{pptv}$ whereas the fraction of both reactive species $(\mathrm{Br}, \mathrm{BrO})$ drops to about
$0.1 \mathrm{pptv}$, each. As the overall abundance of $\mathrm{Br}_{\mathrm{y}}$ at this level is reduced to $0.63 \mathrm{pptv}$ this means that more than $50 \%$ of inorganic bromine is in the form of $\mathrm{HBr}$. In the reference simulation, the fraction is below $15 \%$. The corresponding profiles for $\mathrm{HBr}$ and $\mathrm{Br}_{\mathrm{y}}$ from run $\mathrm{SC}_{\mathrm{c}}$ and $\mathrm{SC}_{\mathrm{c}}$ are presented in Fig. 8. The difference in inorganic bromine between the two simulations represents the loss due to dehydration resulting from the exclusion of heterogeneous chemistry, which ranges from 0.4 to $0.6 \mathrm{pptv}$ depending on the season, being slightly higher compared to our previous study with an earlier model version (0.3-0.4 pptv; mainly attributable to subtle changes in the vertical transport calculation and the update of kinetic data; Aschmann et al., 2011). Considering the assumed detrainment mixing ratio of $1 \mathrm{pptv}$ each for $\mathrm{CHBr}_{3}$ and $\mathrm{CH}_{2} \mathrm{Br}_{2}$, which corresponds to a maximum possible contribution of $5 \mathrm{pptv}$ of $\mathrm{Br}_{\mathrm{y}}$ from short-lived sources, this means that about $10 \%$ of $\mathrm{Br}_{\mathrm{y}}^{\mathrm{VSLS}}$ is lost due to dehydration.

Obviously the partitioning of $\mathrm{Br}_{\mathrm{y}}$ strictly constrains the loss of bromine due to dehydration. As the heterogeneous reactions significantly alter the partitioning we performed the sensitivity calculation $\mathrm{SC} 19_{\mathrm{c}}$ (Table 3) where we changed the uptake coefficient $\gamma$ for the most important reactions that convert adsorbed $\mathrm{HBr}$ (reactions H1, H3, H7; Table 1, Fig. 7) by $\pm 50 \%$. However, the observed effect on $\mathrm{Br}_{\mathrm{y}}$ is negligible $(\approx 0.02 \%)$. Apparently the heterogeneous reactions are efficient to such an extent that the partitioning of $\mathrm{Br}_{\mathrm{y}}$ is robust even against relatively strong changes of the uptake coefficients (the relative uncertainty of the corresponding coefficients is generally lower than $50 \%$; Sander et al., 2011).

Another aspect that could potentially influence the partitioning is a secondary channel of the reaction of $\mathrm{BrO}$ with $\mathrm{HO}_{2}$ (R12). This reaction has a comparatively large turnover rate (Fig. 7) and generally leads to the production of $\mathrm{HOBr}$, though it is possible that there is also a small yield of $\mathrm{HBr}$ (e.g. Mellouki et al., 1994; Bedjanian et al., 2001). Lary (1996) conducted a modeling study which investigates the effect of this additional channel and found that it can significantly increase the abundance of $\mathrm{HBr}$ above $20 \mathrm{~km}$ in mid latitudes. We reproduced this experiment with an assumed yield of $\mathrm{HBr}$-production from reaction $\mathrm{R} 12$ of $0.1 \%$ in run SC17c and can basically confirm the findings of Lary (1996) for mid latitudes. In the tropics, however, we find that the differences in $\mathrm{HBr}$ abundance within the crucial altitude range between LZRH and cold point are negligible $(<0.004 \mathrm{pptv})$.

\subsubsection{Adsorption of $\mathrm{HBr}$}

Section 3.4.1 discusses the importance of $\mathrm{Br}_{\mathrm{y}}$ partitioning for the susceptibility of inorganic bromine to dehydration, however, the actual loss process is the adsorption of these tracers on sedimenting particle surfaces, especially $\mathrm{HBr}$ on ice particles. As described in the model description in Sect. 2, we use a simple parametrization based on Eq. (1) to calculate the reversible uptake of $\mathrm{HBr}$ on ice surfaces, avoiding microphysical details. Since important details of the microphysical 
uptake of bromine species are still unknown or poorly quantified, a significant advantage of this simplified approach is the reduced effort in exploring the parameter space, as there are relatively few variables to consider. In our previous study where we used the same approach (Aschmann et al., 2011), we found that on average only $20-40 \%$ of available $\mathrm{HBr}$ in each model grid box is actually on the ice surface.

Table 3 presents the conducted sensitivity runs together with the main indicator for dehydration efficiency, the mixing ratio of $\mathrm{Br}_{\mathrm{y}}$ upon entering the tropical stratosphere at $380 \mathrm{~K}$ $(\approx 17 \mathrm{~km})$. The primary parameters that have been altered are: (1) temperature $\left( \pm 2 \mathrm{~K}\right.$, run $\left.\mathrm{SC}_{10}\right)$ which constrains the amount of ice in the TTL and consequently the available surface area density $A$; (2) partition coefficient $K_{\operatorname{linC}}$ of Eq. (1) $\left( \pm 50 \%\right.$, run $\left.\mathrm{SC} 13_{\mathrm{c}}\right)$ which regulates the fraction of gas-phase and adsorbed $\mathrm{HBr}$ and (3) sedimentation velocity $\left( \pm 50 \%\right.$, run $\mathrm{SC} 11_{\mathrm{c}}$ ) that controls the displacement and eventual removal of adsorbed species. To single out the impact of the adsorption process and avoid the problem of HBr-depletion by heterogeneous reactions (see Sect. 3.4.1), the mentioned sensitivity runs are calculated without heterogeneous chemistry and thus cannot be compared directly to the reference simulation $\mathrm{SC}_{\mathrm{c}}$ but to run $\mathrm{SC}_{\mathrm{c}}$ which bears the same modification. The relative difference in $\mathrm{Br}_{\mathrm{y}}$ at $380 \mathrm{~K}$ between the sensitivity calculations and run $\mathrm{SC}_{\mathrm{c}}$, i.e. $\left(\mathrm{Br}_{\mathrm{ySC} n}-\mathrm{Br}_{\mathrm{ySC}}\right) / \mathrm{Br}_{\mathrm{y} \mathrm{SC}}$, is illustrated in Fig. 10 .

The impact of the $2 \mathrm{~K}$-temperature modification on inorganic bromine at the top of the TTL is small, about $\pm 0.5 \%$ compared to $\mathrm{SC} 7_{\mathrm{c}}$. This is an interesting result as even this relatively small temperature change significantly alters the amount of $\mathrm{H}_{2} \mathrm{O}( \pm 30 \%$ at $380 \mathrm{~K}$, Fig. 9) and in turn the available ice particle surface, though apparently without notable consequences for the efficiency of the heterogeneous chemistry.

More important is the partition coefficient $K_{\text {linC }}$ for $\mathrm{HBr}$ which directly controls the fraction of this species on the ice surface. Varying this parameter by $\pm 50 \%$ changes the amount of $\mathrm{Br}_{\mathrm{y}}$ by $-5 \%$ and $10 \%$ (for an increase/decrease, respectively), indicating a moderate sensitivity of inorganic bromine to this variable.

The sedimentation velocity of the ice particles constrains the actual loss of adsorbed species. In the model, this velocity is fixed to about $1.5 \mathrm{~km} \mathrm{day}^{-1}$ which corresponds to an average effective particle radius of $10 \mu \mathrm{m}$ according to the utilized parametrization by Böhm (1989). Note that we showed in Aschmann et al. (2011) that the actual particle radii occurring in the model are generally smaller (about $0.5-2 \mu \mathrm{m}$ ) and we do not explicitly calculate microphysical ice particle growth which may lead to larger sizes. In situ aircraft observations of subvisual cirrus clouds in the TTL show that the distribution of ice particle radii peaks at about 5-9 $\mu \mathrm{m}$ (e.g. McFarquhar et al., 2000; Peter et al., 2003; Lawson et al., 2008; Weigel et al., 2011), i.e. our simplified assumption represents a reasonable value. Increasing the fall velocity by

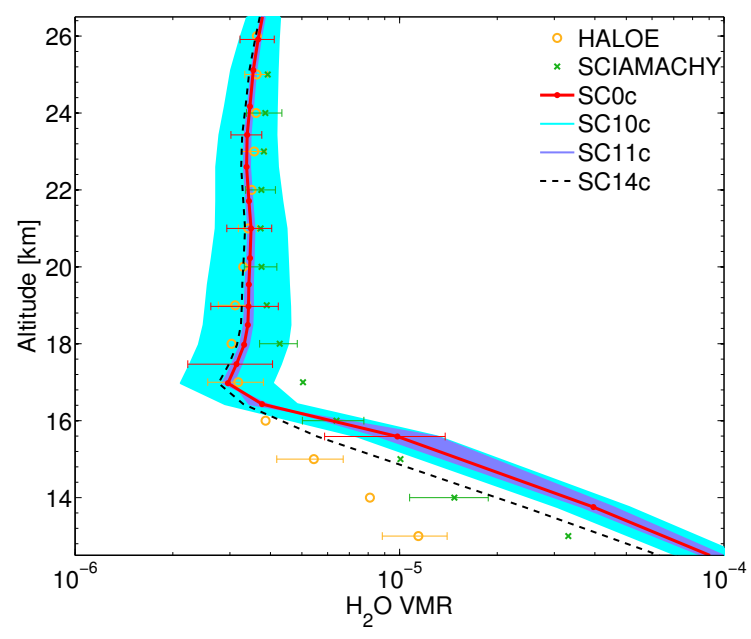

Fig. 9. Averaged tropical profiles $\left(20^{\circ} \mathrm{N}-20^{\circ} \mathrm{S}\right)$ of $\mathrm{H}_{2} \mathrm{O}$ from reference run $\mathrm{SCO}_{\mathrm{c}}$ and the sensitivity calculations $\mathrm{SC} 10_{\mathrm{c}}, \mathrm{SC} 11_{\mathrm{c}}$ and $\mathrm{SC} 14_{\mathrm{c}}$ in comparison to satellite observations from HALOE (Grooß and Russell, 2005) and SCIAMACHY (Rozanov et al., 2011) for 2005. The shadings represent the range between the paired sensitivity runs, i.e. $\mathrm{SC} 10_{\mathrm{c}}, \overline{\mathrm{SC} 10_{\mathrm{c}}}$ and $\mathrm{SC} 11_{\mathrm{c}}, \overline{\mathrm{SC} 11_{\mathrm{c}}}$, respectively.

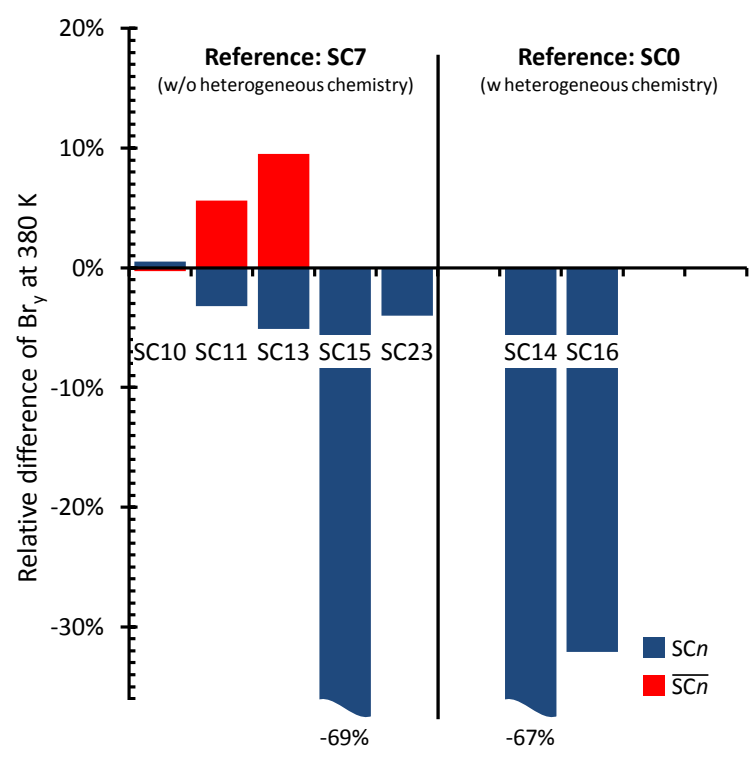

Fig. 10. Relative difference of tropical $\mathrm{Br}_{\mathrm{y}}$ mixing ratio at $380 \mathrm{~K}$ between sensitivity calculation SCn and either SC7 (without heterogeneous chemistry, left) or SC0 (with heterogeneous chemistry, right) for 2006. The blue and red bars denote sensitivity runs where the same parameter is modified in opposite directions ( $\mathrm{SC} n$ and $\overline{\mathrm{SC} n}$, see also Table 3 ).

$50 \%$ leads to a change of $\mathrm{Br}_{\mathrm{y}}$ at $380 \mathrm{~K}$ of $-3 \%$ and $6 \%$ for the opposite effect.

In a recent modeling study that explicitly calculates the microphysical uptake of bromine species (Marécal et al., 2012), the authors assume that tracers on ice particles are instantly washed out, arguing that the particles quickly grow 
by riming into fast-falling graupel and hail particles in the free troposphere. There is indeed observational evidence that even at the tropopause large hydro meteors can be formed with effective radii above $100 \mu \mathrm{m}$ in temporary layers of significant water vapor supersaturation introduced by displacement of air parcels due to gravity waves (e.g., Jensen et al., 1996, 2008), so it is possible that this drastical assumption is also applicable to ice particles in the TTL. We tested this hypothesis in our sensitivity calculations $\mathrm{SC} 14_{\mathrm{c}}$ and $\mathrm{SC} 15_{\mathrm{c}}$. In both runs ice and adsorbed $\mathrm{HBr}$ are instantaneously removed whereas $\mathrm{SC} 14_{\mathrm{c}}$ contains heterogeneous chemistry and $\mathrm{SC} 15_{\mathrm{c}}$ not. Figure 10 shows the drastic removal of $\mathrm{Br}_{\mathrm{y}}$ under this condition, almost reaching $-70 \%$ for the latter run. This does not change much if heterogeneous reactions are taken into account (SC14 $), 67 \%$ of inorganic bromine at $380 \mathrm{~K}$ or $1.23 \mathrm{pptv}$ is lost. Considering that at $380 \mathrm{~K} 1.57 \mathrm{pptv}$ of $\mathrm{Br}_{\mathrm{y}}$ is originated from short-lived source gases (Fig. 3), this means that a large fraction of bromine from VSLS which is in product gas form is removed $(\approx 80 \%)$. However, when compared to the total amount of bromine from VSLS ( $5 \mathrm{pptv})$, the loss does not exceed $25 \%$ even under these extreme circumstances since the majority of VSLS in this altitude region are still intact and are therefore not affected by scavenging. Interestingly, a change of the sedimentation velocity $\left(\mathrm{SC} 11_{\mathrm{c}}\right)$ or even the instantaneous removal of ice particles $\left(\mathrm{SC}_{1} 4_{\mathrm{c}}\right)$ does not significantly affect the resulting water vapor profile in the TTL region, as illustrated in Fig. 9. In fact, the resulting profile from run $\mathrm{SC}_{1} 4_{\mathrm{c}}$ is even closer to the satellite observations below $15 \mathrm{~km}$ than the reference simulation $\mathrm{SCO}_{\mathrm{c}}$.

Finally, we tested the hypothesis that $\mathrm{HOBr}$ is adsorbed on ice surfaces as well. A kinetic study of Chu and Chu (1999) found that continued exposure of ice films to $\mathrm{HOBr}$ eventually leads to saturation. However, the process cannot be described as a Langmuir process and is difficult to quantify. Nonetheless, for our sensitivity study we simply assume that the adsorption of $\mathrm{HOBr}$ on ice proceeds identically to the one of $\mathrm{HBr}$, i.e. we apply Eq. (1) with the same value for $K_{\text {linC }}$ also to HOBr. Run SC16 contains the standard heterogeneous chemistry whereas $\mathrm{SC} 23_{\mathrm{c}}$ was calculated without. In the latter case, the response to this effect in the $\mathrm{Br}_{\mathrm{y}}$ mixing ratio is about $-4 \%$ compared to the unperturbed run without heterogeneous reactions $\left(\mathrm{SC}_{\mathrm{c}}\right.$; Fig. 10). However, when comparing the runs with these reactions included, $\mathrm{SC} 16_{\mathrm{c}}$ and $\mathrm{SC} 0_{\mathrm{c}}$, the impact is significantly larger, exceeding $-30 \%$. As a matter of fact even the absolute mixing ratio of $\mathrm{Br}_{\mathrm{y}}$ is lower, $1.25 / 1.32 \mathrm{pptv}$ for $\mathrm{SC} 16_{\mathrm{c}} / \mathrm{SC} 23_{\mathrm{c}}$ in contrast to $1.83 / 1.37 \mathrm{pptv}$ for $\mathrm{SC}_{\mathrm{c}} / \mathrm{SC} 7_{\mathrm{c}}$. This means that in this case the heterogeneous chemistry actually promotes the loss of inorganic bromine due to dehydration in contrast to our previous findings, as long as $\mathrm{HOBr}$ is adsorbed as well. This is because the partitioning among the bromine reservoir species is shifted from $\mathrm{HBr}$ towards $\mathrm{HOBr}$ by heterogeneous conversion, especially during nighttime (Fig. 7). In fact, a partitioning analysis as presented in Fig. 7 but for run $\mathrm{SC}_{\mathrm{c}}$ reveals (not shown here) that the $\mathrm{HOBr}$ mixing ratios are smaller by a factor of 3-5 when heterogeneous chemistry is switched off. Related to the available amount of bromine from shortlived sources ( 5 pptv), the loss due to dehydration under this circumstances adds up to about $12 \%$.

\section{Discussion and conclusions}

This study investigates the processes that control source and product gas injection of bromine from short-lived source gases and the associated loss of inorganic bromine in the TTL. The sensitivity calculations are conducted utilizing the 3-D isentropic CTM framework that has been already evaluated against observations and was used for related topics in earlier studies (Aschmann et al., 2009, 2011). In the model, we consider the two most abundant bromine VSLS, bromoform and dibromomethane, each with an assumed uniform boundary layer mixing ratio of $1 \mathrm{pptv}$, thus the maximum possible contribution of VSLS to inorganic bromine would be 5 pptv. This is in good agreement with available observations (Fig. 6), though we do not include some minor bromine short-lived source gases which may even increase the contribution of VSLS by 1 pptv to aproximately 6 pptv (e.g. Hossaini et al., 2012).

Our results suggest that even for the short-lived tracers source gas injection is the dominant pathway into the stratosphere. The relative fraction of SGI averaged in the tropics varies with convective and large-scale vertical transport in the range of $40-60 \%$ and $92-95 \%$ for $\mathrm{CHBr}_{3}$ and $\mathrm{CH}_{2} \mathrm{Br}_{2}$, respectively. This is in good agreement with the modeling studies of Hossaini et al. $(2010,2012)$ who find SGI fractions of about $50 \%$ for $\mathrm{CHBr}_{3}$ and $90 \%$ for $\mathrm{CH}_{2} \mathrm{Br}_{2}$. Brinckmann et al. (2012) give a lower estimate, 21/74\% for $\mathrm{CHBr}_{3} / \mathrm{CH}_{2} \mathrm{Br}_{2}$, based on a single balloon observation above Teresina, Brazil. In another modeling study, Liang et al. (2010) find a fraction of $50 \%$ for both VSLS combined, which is also lower than in our model $(68 \%$ for both species). The absolute values of SGI/PGI mixing ratios, however, are difficult to compare as they are directly dependent on the assumed emissions or boundary layer concentrations, which may vary significantly between the different studies and are still poorly constrained by observations due to the scarcity of data. Our average tropical SGI/PGI mixing ratios are 1.54/1.45 pptv for $\mathrm{CHBr}_{3}$ and 1.88/0.12 pptv for $\mathrm{CH}_{2} \mathrm{Br}_{2}$. Especially in the case of $\mathrm{CHBr}_{3}$ the tropical mixing ratio at $380 \mathrm{~K}$ or $17 \mathrm{~km}$ in our model with about $0.5 \mathrm{pptv}$ is likely highbiased, as the available aircraft and balloon measurements of this species generally show lower values at this altitude, in the range of $0-0.3$ pptv (e.g. Kroon et al., 2008; Laube et al., 2008; Aschmann et al., 2009; Hossaini et al., 2010; Liang et al., 2010; Toon et al., 2010; Aschmann, 2011; Hossaini et al., 2012; Ordóñez et al., 2012; Brinckmann et al., 2012, see also Fig. 6). The most probable explanation for this discrepancy is the simplified treatment of convective uplifting of short-lived source gases in the B3DCTM. As our 
model does not explicitly contain the boundary layer and the free troposphere, we have to assume a fixed uniform detrainment mixing ratio for VSLS although previous studies clearly demonstrate the importance of individual emission regions (e.g. Levine et al., 2007; Aschmann et al., 2009; Pisso et al., 2010; Bergman et al., 2012). However, as the relative importance of the investigated processes is largely independent from the absolute amount of available bromine, we are confident that this has only a minor impact on our main results.

The extent of source gas injection of the investigated VSLS is not very sensitive to changes in the photochemical decay in general. More important, particularly for shorterlived species like $\mathrm{CHBr}_{3}$, are variations in convective and large-scale vertical transport, in particular in the crucial range between the LZRH and the cold point. This confirms the findings of a recent study by Bergman et al. (2012), who did a detailed analysis of vertical transport in the TTL and came to a similar conclusion. For the considerable longerlived $\mathrm{CH}_{2} \mathrm{Br}_{2}$, the overall sensitivity is smaller and the photochemical degradation is of equal importance compared to the vertical transport.

The second part of this study investigates the impact of dehydration on inorganic bromine in the TTL. In our previous study (Aschmann et al., 2011) we found that loss of $\mathrm{Br}_{\mathrm{y}}$ due to dehydration is negligible, in contrast to most earlier modeling studies which used a fixed washout lifetime for $\mathrm{Br}_{\mathrm{y}}$ (e.g. Dvortsov et al., 1999; Nielsen and Douglass, 2001; Warwick et al., 2006; Hossaini et al., 2010). In the present study, we look into the involved processes in more detail to further refine our results. Adsorption of soluble species on ice particles may play an important role in the exceptional cold TTL and as only $\mathrm{HBr}$ is currently known to be efficiently adsorbed on ice (Crowley et al., 2010), the partitioning of $\mathrm{Br}_{\mathrm{y}}$ is a critical factor. Our partitioning analysis shows that heterogeneous reactions on ice surfaces efficiently shift the equilibrium in the $\mathrm{Br}_{\mathrm{y}}$ family from $\mathrm{HBr}$ towards the insoluble $\mathrm{Br}$ and $\mathrm{BrO}$. The average tropical $\mathrm{HBr} / \mathrm{Br}_{\mathrm{y}}$ fraction drops from about $50 \%$ to $15 \%$ in the range between LZRH and cold point, if heterogeneous reactions are taken into account, strictly constraining the possible loss of $\mathrm{Br}_{\mathrm{y}}$ due to dehydration in the first place. Apparently these reactions are efficient to such an extent that even relatively strong changes to the associated uptake coefficients $( \pm 50 \%)$ do not alter the $\mathrm{Br}_{\mathrm{y}}$ partitioning significantly, as shown by our sensitivity calculations. Due to the efficiency of the heterogeneous chemistry in converting $\mathrm{HBr}$ we find no considerable loss of $\mathrm{Br}_{\mathrm{y}}$. In contrast, if these reactions are switched off, 0.4 to 0.6 pptv of $\mathrm{Br}_{\mathrm{y}}$ are scavenged (i.e. about $10 \%$ of $\mathrm{Br}_{\mathrm{y}}^{\mathrm{VSLS}}$ ), which is slightly higher compared to our previous estimate (0.3-0.4 pptv; Aschmann et al., 2011). The relative loss is conspicuously smaller compared to previous modeling studies which used a simple washout lifetime for $\mathrm{Br}_{\mathrm{y}}(60 \%$; Hossaini et al., 2010) or remove a fixed percentage of $\mathrm{Br}_{\mathrm{y}}$ upon entering the stratosphere (38\%; Schofield et al., 2011) but is consistent with the results of Liang et al. (2010) who modeled the dehydration process in more complexity and found a relative loss of $5 \%$ in the upper troposphere.

The adsorption process itself that leads to the actual loss of bromine in the TTL is not sensitive to moderate changes in temperature. Although the amount of ice and therefore the available particle surface is drastically changed by even a relatively small change of ambient temperature (in our case, $\pm 2 \mathrm{~K}$ ), the loss of $\mathrm{Br}_{\mathrm{y}}$ is not significantly affected. More important are the sedimentation velocity of ice particles and the partition coefficient $K_{\text {linC }}$ for $\mathrm{HBr}$. A $\pm 50 \%$ perturbation of these variables yields a change of $\mathrm{Br}_{\mathrm{y}}$ loss in the range of $\pm 3-10 \%$. The removal of $\mathrm{Br}_{\mathrm{y}}$ becomes more effective if adsorbed species on ice particles are instantaneously removed. Marécal et al. (2012) argued in their modeling study about the transport and uptake of bromine species in the TTL that the majority of ice particles quickly grow by riming and therefore acquire high fall velocities, so that the assumption of instantaneous removal is justified. If this is indeed the case also for the TTL, our sensitivity calculation suggests that about $1.2 \mathrm{pptv}$ of $\mathrm{Br}_{\mathrm{y}}^{\mathrm{VSLS}}$ is lost which corresponds to $80 \%$ of the available product gas from VSLS in the upper TTL region (25\% of the total contribution of VSLS to stratospheric bromine). Finally, we tested the hypothesis that $\mathrm{HOBr}$ is adsorbed on ice the same way as HBr. Under this circumstances, about $0.6 \mathrm{pptv}$ or $12 \%$ of $\mathrm{Br}_{\mathrm{y}}^{\mathrm{VSLS}}$ is removed. This is caused by the fact that the heterogeneous chemistry shifts the balance in the $\mathrm{Br}_{\mathrm{y}}$ family away from $\mathrm{HBr}$ not only towards $\mathrm{Br}$ and $\mathrm{BrO}$, but also towards $\mathrm{HOBr}$ which in turn is deposited on the ice.

In a condensed form, the main points of our study can be summarized as follows:

1. The most crucial factor for the contribution of VSLS to stratospheric bromine is the extent of source gas injection for these species, as they are not affected by scavenging. The fraction of source gas injection is about $50 \%$ for $\mathrm{CHBr}_{3}$ and $94 \%$ for $\mathrm{CH}_{2} \mathrm{Br}_{2}$. In the case of $\mathrm{CHBr}_{3}$, our results suggest that this fraction is critically dependent on vertical transport, especially convection above the level of zero radiative heating, in contrast to uncertainties in photochemical degradation which are remarkably less important. For $\mathrm{CH}_{2} \mathrm{Br}_{2}$, the overall sensitivity is smaller as it is less reliant on rapid vertical transport in order to reach the stratosphere due to its considerable longer lifetime.

2. Since only certain species (more precisely: only $\mathrm{HBr}$ ) among the family of inorganic bromine are susceptible to adsorption on ice particles, the partitioning within the family is an important factor. We find that the partitioning is clearly dominated by heterogeneous chemistry which shifts the equilibrium away from $\mathrm{HBr}$ towards $\mathrm{Br}$, $\mathrm{BrO}$, and, to a lesser extent, $\mathrm{HOBr}$. 
3. Heterogeneous activation effectively prevents loss of inorganic bromine, if only $\mathrm{HBr}$ is assumed to be adsorbed on ice particles. If these reactions are ignored, about $10 \%$ of $\mathrm{Br}_{\mathrm{y}}^{\mathrm{VSLS}}$ can be removed by scavenging. A loss of similar magnitude is examined if $\mathrm{HOBr}$ is assumed to adsorb on ice as efficiently as $\mathrm{HBr}$. To improve our understanding of the role of dehydration for the removal of inorganic bromine it is therefore crucial to further extend our knowledge about surface and uptake processes on particles also for other species than $\mathrm{HBr}$.

4. Ice particle growth represents an uncertainty factor in most simulations, as this process is generally not microphysically resolved in global models though it is directly related to the sedimentation velocity of ice in the TTL. We found no large sensitivity to moderate changes of this quantity in our model, only if the majority of ice particles grows fast enough to justify an instantaneous removal of ice from the TTL up to $25 \%$ of bromine from VSLS may be lost.

5. We achieve best agreement between the model and observational data if we assume $6 \mathrm{pptv}$ of bromine from VSLS in convective updrafts $(3,2$ and 1 pptv from $\mathrm{CHBr}_{3}, \mathrm{CH}_{2} \mathrm{Br}_{2}$ and minor VSLS, respectively). Consequently, we find a most likely contribution of VSLS to stratospheric bromine in the range of 4.5-6 pptv. Though the given range is directly dependent on the assumed sources which are difficult to constrain and we ignore important factors regarding the strength and spatial distribution of VSLS emissions in our approach, it is consistent on the one hand with observations of source gases in the troposphere and on the other hand with $\mathrm{Br}_{\mathrm{y}}$ estimates derived from $\mathrm{BrO}$ observations in the stratosphere.

Acknowledgements. We thank the three anonymous referees for their help in improving the manuscript. Parts of this work were supported by the EU project SHIVA (226224-FP7-ENV-2008-1), the project DACCS as part of the DFG priority programme CAWSES and the DFG research unit SHARP. ERA-Interim data were provided through the ECMWF special project DECDIO.

Edited by: M. Dameris

\section{References}

Aschmann, J.: Impact of Very Short-Lived Substances on Stratospheric Bromine Loading, $\mathrm{Ph}$. D. thesis, Institute of Environmental Physics, University of Bremen, available at: http:// nbn-resolving.de/urn:nbn:de:gbv:46-00102329-11, (last access: 20 November 2012) 2011.

Aschmann, J., Sinnhuber, B.-M., Atlas, E. L., and Schauffler, S. M.: Modeling the transport of very short-lived substances into the tropical upper troposphere and lower stratosphere, Atmos. Chem. Phys., 9, 9237-9247, doi:10.5194/acp-9-9237-2009, 2009.
Aschmann, J., Sinnhuber, B.-M., Chipperfield, M. P., and Hossaini, R.: Impact of deep convection and dehydration on bromine loading in the upper troposphere and lower stratosphere, Atmos. Chem. Phys., 11, 2671-2687, doi:10.5194/acp-11-26712011, 2011.

Ashfold, M. J., Harris, N. R. P., Atlas, E. L., Manning, A. J., and Pyle, J. A.: Transport of short-lived species into the Tropical Tropopause Layer, Atmos. Chem. Phys., 12, 6309-6322, doi:10.5194/acp-12-6309-2012, 2012.

Bedjanian, Y., Riffault, V., and Poulet, G.: Kinetic study of the reactions of $\mathrm{BrO}$ radicals with $\mathrm{HO}_{2}$ and $\mathrm{DO}_{2}$, J. Phys. Chem. A, 105, 3167-3175, doi:10.1021/jp0032255, 2001.

Bergman, J. W., Jensen, E. J., Pfister, L., and Yang, Q.: Seasonal differences of vertical-transport efficiency in the tropical tropopause layer: on the interplay between tropical deep convection, largescale vertical ascent, and horizontal circulationes, J. Geophys. Res.-Atmos., 117, D05302, doi:10.1029/2011JD016992, 2012.

Böhm, H. P.: A general equation for the terminal fall speed of solid hydrometeors, J. Atmos. Sci., 46, 2419-2427, 1989.

Brinckmann, S., Engel, A., Bönisch, H., Quack, B., and Atlas, E.: Short-lived brominated hydrocarbons - observations in the source regions and the tropical tropopause layer, Atmos. Chem. Phys., 12, 1213-1228, doi:10.5194/acp-12-1213-2012, 2012.

Burkholder, J. B., Ravishankara, A. R., and Solomon, S.: UV visible and IR absorption cross-sections of $\mathrm{BrONO}_{2}$, J. Geophys. Res.Atmos., 100, 16793-16800, 1995.

Butler, J. H., King, D. B., Lobert, J. M., Montzka, S. A., YvonLewis, S. A., Hall, B. D., Warwick, N. J., Mondeel, D. J., Aydin, M., and Elkins, J. W.: Oceanic distributions and emissions of short-lived halocarbons, Global Biogeochem. Cy., 21, GB1023, doi:10.1029/2006GB002732, 2007.

Carpenter, L. J. and Liss, P. S.: On temperate sources of bromoform and other reactive organic bromine gases, J. Geophys. Res.Atmos., 105, 20539-20547, 2000.

Carpenter, L. J., Jones, C. E., Dunk, R. M., Hornsby, K. E., and Woeltjen, J.: Air-sea fluxes of biogenic bromine from the tropical and North Atlantic Ocean, Atmos. Chem. Phys., 9, 1805-1816, doi:10.5194/acp-9-1805-2009, 2009.

Chipperfield, M. P.: Multiannual simulations with a threedimensional chemical transport model, J. Geophys. Res.-Atmos., 104, 1781-1805, 1999.

Chu, L. and Chu, L.: Heterogeneous interaction and reaction of $\mathrm{HOBr}$ on ice films, J. Phys. Chem. A, 103, 8640-8649, doi:10.1021/jp991136q, 1999.

Corti, T., Luo, B. P., Peter, T., Vömel, H., and Fu, Q.: Mean radiative energy balance and vertical mass fluxes in the equatorial upper troposphere and lower stratosphere, Geophys. Res. Lett., 32, L06802, doi:10.1029/2004GL021889, 2005.

Crowley, J. N., Ammann, M., Cox, R. A., Hynes, R. G., Jenkin, M. E., Mellouki, A., Rossi, M. J., Troe, J., and Wallington, T. J.: Evaluated kinetic and photochemical data for atmospheric chemistry: Volume $\mathrm{V}$ - heterogeneous reactions on solid substrates, Atmos. Chem. Phys., 10, 9059-9223, doi:10.5194/acp-10-9059-2010, 2010.

Daniel, J. S. and Velders, G. J. M.: A Focus on Information and Options for Policymakers, Scientific assessment of ozone depletion: 2010, Global Ozone Research and Monitoring Project, Report No. 52, Chapter 5, World Meteorological Organization, Geneva, 
Switzerland, 2011.

Dee, D. P., Uppala, S. M., Simmons, A. J., Berrisford, P., Poli, P., Kobayashi, S., Andrae, U., Balmaseda, M. A., Balsamo, G., Bauer, P., Bechtold, P., Beljaars, A. C. M., van de Berg, L., Bidlot, J., Bormann, N., Delsol, C., Dragani, R., Fuentes, M., Geer, A. J., Haimberger, L., Healy, S. B., Hersbach, H., Hólm, E. V., Isaksen, L., Kållberg, P., Köhler, M., Matricardi, M., McNally, A. P., Monge-Sanz, B. M., Morcrette, J.-J., Park, B.K., Peubey, C., de Rosnay, P., Tavolato, C., Thépaut, J.-N., and Vitart, F.: The ERA-interim reanalysis: configuration and performance of the data assimilation system, Q. J. Roy. Meteor. Soc., 137, 553-597, doi:10.1002/qj.828, 2011.

Dessler, A. E.: The effect of deep, tropical convection on the tropical tropopause layer, J. Geophys. Res.-Atmos., 107, 4033, doi:10.1029/2001JD000511, 2002.

Dorf, M., Butler, J. H., Butz, A., Camy-Peyret, C., Chipperfield, M. P., Kritten, L., Montzka, S. A., Simmes, B., Weidner, F., and Pfeilsticker, K.: Long-term observations of stratospheric bromine reveal slow down in growth, Geophys. Res. Lett., 33, doi:10.1029/2006GL027714, 2006.

Dvortsov, V. L., Geller, M. A., Solomon, S., Schauffler, S. M., Atlas, E. L., and Blake, D. R.: Rethinking reactive halogen budgets in the midlatitude lower stratosphere, Geophys. Res. Lett., 26, 1699-1702, 1999.

Fueglistaler, S., Bonazzola, M., Haynes, P. H., and Peter, T.: Stratospheric water vapor predicted from the Lagrangian temperature history of air entering the stratosphere in the tropics, J. Geophys. Res.-Atmos., 110, D08107, doi:10.1029/2004JD005516, 2005.

Fueglistaler, S., Dessler, A. E., Dunkerton, T. J., Folkins, I., Fu, Q., and Mote, P. W.: Tropical Tropopause Layer, Rev. Geophys., 47, RG1004, doi:10.1029/2008RG000267, 2009.

Gettelman, A., Lauritzen, P. H., Park, M., and Kay, J. E.: Processes regulating short-lived species in the tropical tropopause layer, J. Geophys. Res.-Atmos., 114, D13303, doi:10.1029/2009JD011785, 2009.

Gilles, M. K., Turnipseed, A. A., Burkholder, J. B., Ravishankara, A. R., and Solomon, S.: Kinetics of the IO radical 2. Reaction of IO with BrO, J. Phys. Chem. A, 101, 5526-5534, 1997.

Grooß, J.-U. and Russell III, James M.: Technical note: A stratospheric climatology for $\mathrm{O}_{3}, \mathrm{H}_{2} \mathrm{O}, \mathrm{CH}_{4}, \mathrm{NO}_{\mathrm{x}}, \mathrm{HCl}$ and $\mathrm{HF}$ derived from HALOE measurements, Atmos. Chem. Phys., 5, 2797-2807, doi:10.5194/acp-5-2797-2005, 2005.

Holton, J. R. and Gettelman, A.: Horizontal transport and the dehydration of the stratosphere, Geophys. Res. Lett., 28, 2799-2802, 2001.

Hossaini, R., Chipperfield, M. P., Monge-Sanz, B. M., Richards, N. A. D., Atlas, E., and Blake, D. R.: Bromoform and dibromomethane in the tropics: a 3-D model study of chemistry and transport, Atmos. Chem. Phys., 10, 719-735, doi:10.5194/acp-10-719-2010, 2010.

Hossaini, R., Chipperfield, M. P., Feng, W., Breider, T. J., Atlas, E., Montzka, S. A., Miller, B. R., Moore, F., and Elkins, J.: The contribution of natural and anthropogenic very short-lived species to stratospheric bromine, Atmos. Chem. Phys., 12, 371-380, doi:10.5194/acp-12-371-2012, 2012.

Ingham, T., Bauer, D., Landgraf, J., and Crowley, J. N.: Ultravioletvisible absorption cross sections of gaseous $\mathrm{HOBr}$, J. Phys. Chem. A, 102, 3293-3298, 1998.
Jensen, E., Toon, O., Pfister, L., and Selkirk, H.: Dehydration of the upper troposphere and lower stratosphere by subvisible cirrus clouds near the tropical tropopause, Geophys. Res. Lett., 23, 825-828, doi:10.1029/96GL00722, 1996.

Jensen, E. J., Pfister, L., Bui, T. V., Lawson, P., Baker, B., Mo, Q., Baumgardner, D., Weinstock, E. M., Smith, J. B., Moyer, E. J., Hanisco, T. F., Sayres, D. S., Clair, J. M. St., Alexander, M. J., Toon, O. B., and Smith, J. A.: Formation of large $(\simeq 100 \mu \mathrm{m})$ ice crystals near the tropical tropopause, Atmos. Chem. Phys., 8, 1621-1633, doi:10.5194/acp-8-1621-2008, 2008.

Kerkweg, A., Jöckel, P., Warwick, N., Gebhardt, S., Brenninkmeijer, C. A. M., and Lelieveld, J.: Consistent simulation of bromine chemistry from the marine boundary layer to the stratosphere - Part 2: Bromocarbons, Atmos. Chem. Phys., 8, 5919-5939, doi:10.5194/acp-8-5919-2008, 2008.

Kroon, M., Petropavlovskikh, I., Shetter, R., Hall, S., Ullmann, K., Veefkind, J. P., McPeters, R. D., Browell, E. V., and Levelt, P. F.: OMI total ozone column validation with Aura-AVE CAFS observations, J. Geophys. Res.-Atmos., 113, D15S13, doi:10.1029/2007JD008795, 2008.

Krysztofiak, G., Catoire, V., Poulet, G., Marecal, V., Pirre, M., Louis, F., Canneaux, S., and Josse, B.: Detailed modeling of the atmospheric degradation mechanism of veryshort lived brominated species, Atmos. Environ., 59, 514-532, doi:10.1016/j.atmosenv.2012.05.026, 2012.

Lary, D. J.: Gas phase atmospheric bromine photochemistry, J. Geophys. Res.-Atmos., 101, 1505-1516, 1996.

Laube, J. C., Engel, A., Bönisch, H., Möbius, T., Worton, D. R., Sturges, W. T., Grunow, K., and Schmidt, U.: Contribution of very short-lived organic substances to stratospheric chlorine and bromine in the tropics - a case study, Atmos. Chem. Phys., 8, 7325-7334, doi:10.5194/acp-8-7325-2008, 2008.

Law, K. S. and Sturges, W. T.: Halogenated very short-lived substances, Scientific assessment of ozone depletion: 2006, Global Ozone Research and Monitoring Project, Report No. 50, Chapter 2, World Meteorological Organization, Geneva, Switzerland, 2007.

Lawson, R. P., Pilson, B., Baker, B., Mo, Q., Jensen, E., Pfister, L., and Bui, P.: Aircraft measurements of microphysical properties of subvisible cirrus in the tropical tropopause layer, Atmos. Chem. Phys., 8, 1609-1620, doi:10.5194/acp-8-1609-2008, 2008.

Levine, J. G., Braesicke, P., Harris, N. R. P., Savage, N. H., and Pyle, J. A.: Pathways and timescales for troposphere-to-stratosphere transport via the tropical tropopause layer and their relevance for very short lived substances, J. Geophys. Res.-Atmos., 112, doi:10.1029/2005JD006940, 2007.

Liang, Q., Stolarski, R. S., Kawa, S. R., Nielsen, J. E., Douglass, A. R., Rodriguez, J. M., Blake, D. R., Atlas, E. L., and Ott, L. E.: Finding the missing stratospheric $\mathrm{Br}_{\mathrm{y}}$ : a global modeling study of $\mathrm{CHBr}_{3}$ and $\mathrm{CH}_{2} \mathrm{Br}_{2}$, Atmos. Chem. Phys., 10, 2269-2286, doi:10.5194/acp-10-2269-2010, 2010.

Marécal, V., Pirre, M., Krysztofiak, G., Hamer, P. D., and Josse, B.: What do we learn about bromoform transport and chemistry in deep convection from fine scale modelling?, Atmos. Chem. Phys., 12, 6073-6093, doi:10.5194/acp-12-6073-2012, 2012.

Maric, D., Burrows, J. P., and Moortgat, G. K.: A study of the UVvisible absorption-spectra of $\mathrm{Br}_{2}$ and $\mathrm{BrCl}$, J. Photoch. Photobio. A, 83, 179-192, 1994. 
McFarquhar, G., Heymsfield, A., Spinhirne, J., and Hart, B.: Thin and subvisual tropopause tropical cirrus: observations and radiative impacts, J. Atmos. Sci., 57, 1841-1853, doi:10.1175/15200469(2000)057<1841:TASTTC> 2.0.CO;2, 2000.

McLinden, C. A., Haley, C. S., Lloyd, N. D., Hendrick, F., Rozanov, A., Sinnhuber, B.-M., Goutail, F., Degenstein, D. A., Llewellyn, E. J., Sioris, C. E., Van Roozendael, M., Pommereau, J.-P., Lotz, W., and Burrows, J. P.: Odin/OSIRIS observations of stratospheric BrO: retrieval methodology, climatology, and inferred $\mathrm{Br}_{\mathrm{y}}$, J. Geophys. Res.-Atmos., 115, D15308, doi:10.1029/2009JD012488, 2010.

Mellouki, A., Talukdar, R., and Howard, C.: Kinetics of the reactions of $\mathrm{HBr}$ with $\mathrm{O}_{3}$ and $\mathrm{HO}_{2}$ - the yield of $\mathrm{HBr}$ from $\mathrm{HO}_{2}+\mathrm{BrO}$, J. Geophys. Res.-Atmos., 99, 22949-22954, doi:10.1029/94JD02144, 1994.

Montzka, S. A. and Reimann, S.: Ozone-Depleting Substances (ODSs) and Related Chemicals, Scientific assessment of ozone depletion: 2010, Global Ozone Research and Monitoring Project, Report No. 52, Chapter 1, World Meteorological Organization, Geneva, Switzerland, 2011.

Nee, J. B., Suto, M., and Lee, L. C.: Quantitative spectroscopy study of $\mathrm{HBr}$ in the $105-235 \mathrm{~nm}$ region, J. Chem. Phys., 85, 49194924, 1986.

Nielsen, J. E. and Douglass, A. R.: Simulation of bromoform's contribution to stratospheric bromine, J. Geophys. Res.-Atmos., 106, 8089-8100, 2001.

O’Brien, L. M., Harris, N. R. P., Robinson, A. D., Gostlow, B., Warwick, N., Yang, X., and Pyle, J. A.: Bromocarbons in the tropical marine boundary layer at the Cape Verde Observatory - measurements and modelling, Atmos. Chem. Phys., 9, 9083-9099, doi:10.5194/acp-9-9083-2009, 2009.

Ordóñez, C., Lamarque, J.-F., Tilmes, S., Kinnison, D. E., Atlas, E. L., Blake, D. R., Sousa Santos, G., Brasseur, G., and Saiz-Lopez, A.: Bromine and iodine chemistry in a global chemistry-climate model: description and evaluation of very short-lived oceanic sources, Atmos. Chem. Phys., 12, 14231447, doi:10.5194/acp-12-1423-2012, 2012.

Peter, Th., Luo, B. P., Wirth, M., Kiemle, C., Flentje, H., Yushkov, V. A., Khattatov, V., Rudakov, V., Thomas, A., Borrmann, S., Toci, G., Mazzinghi, P., Beuermann, J., Schiller, C., Cairo, F., Di Donfrancesco, G., Adriani, A., Volk, C. M., Strom, J., Noone, K., Mitev, V., MacKenzie, R. A., Carslaw, K. S., Trautmann, T., Santacesaria, V., and Stefanutti, L.: Ultrathin Tropical Tropopause Clouds (UTTCs): I. Cloud morphology and occurrence, Atmos. Chem. Phys., 3, 1083-1091, doi:10.5194/acp-3-1083-2003, 2003.

Pisso, I., Haynes, P. H., and Law, K. S.: Emission location dependent ozone depletion potentials for very short-lived halogenated species, Atmos. Chem. Phys., 10, 12 025-12 036, doi:10.5194/acp-10-12025-2010, 2010.

Quack, B. and Wallace, D. W. R.: Air-sea flux of bromoform: Controls, rates, and implications, Global Biochem. Cy., 17, 1023, doi:10.1029/2002GB001890, 2003.

Rozanov, A., Weigel, K., Bovensmann, H., Dhomse, S., Eichmann, K.-U., Kivi, R., Rozanov, V., Vömel, H., Weber, M., and Burrows, J. P.: Retrieval of water vapor vertical distributions in the upper troposphere and the lower stratosphere from SCIAMACHY limb measurements, Atmos. Measur. Tech., 4, 933954, doi:10.5194/amt-4-933-2011, 2011.
Salawitch, R.: Atmospheric chemistry - biogenic bromine, Nature, 439, 275-277, doi:10.1038/439275a, 2006.

Salawitch, R. J., Canty, T., Kurosu, T., Chance, K., Liang, Q., da Silva, A., Pawson, S., Nielsen, J. E., Rodriguez, J. M., Bhartia, P. K., Liu, X., Huey, L. G., Liao, J., Stickel, R. E., Tanner, D. J., Dibb, J. E., Simpson, W. R., Donohoue, D., Weinheimer, A., Flocke, F., Knapp, D., Montzka, D., Neuman, J. A., Nowak, J. B., Ryerson, T. B., Oltmans, S., Blake, D. R., Atlas, E. L., Kinnison, D. E., Tilmes, S., Pan, L. L., Hendrick, F., Van Roozendael, M., Kreher, K., Johnston, P. V., Gao, R. S., Johnson, B., Bui, T. P., Chen, G., Pierce, R. B., Crawford, J. H., and Jacob, D. J.: A new interpretation of total column BrO during Arctic spring, Geophys. Res. Lett., 37, L21805, doi:10.1029/2010GL043798, 2010.

Sander, S. P., Abbatt, J., Barker, J. R., Burkholder, J. B., Friedl, R. R., Golden, D. M., Huie, R. E., Kolb, C. E., Kurylo, M. J., Moortgat, G. K., Orkin, V. L., and Wine, P. H.: Chemical Kinetics and Photochemical Data for Use in Atmospheric Studies: Evaluation No. 17, JPL Publ. 10-6, Jet Propul. Lab., Pasadena, CA, USA, 2011.

Schofield, R., Fueglistaler, S., Wohltmann, I., and Rex, M.: Sensitivity of stratospheric $\mathrm{Br}_{\mathrm{y}}$ to uncertainties in very short lived substance emissions and atmospheric transport, Atmos. Chem. Phys., 11, 1379-1392, doi:10.5194/acp-11-1379-2011, 2011.

Sherwood, S. C. and Dessler, A. E.: A model for transport across the tropical tropopause, J. Atmos. Sci., 58, 765-779, 2001.

Sinnhuber, B.-M. and Folkins, I.: Estimating the contribution of bromoform to stratospheric bromine and its relation to dehydration in the tropical tropopause layer, Atmos. Chem. Phys., 6, 4755-4761, doi:10.5194/acp-6-4755-2006, 2006.

Sinnhuber, B.-M., Weber, M., Amankwah, A., and Burrows, J. P.: Total ozone during the unusual Antarctic winter of 2002, Geophys. Res. Lett., 30, 1580, doi:10.1029/2002GL016798, 2003.

Sinnhuber, B.-M., Rozanov, A., Sheode, N., Afe, O. T., Richter, A., Sinnhuber, M., Wittrock, F., Burrows, J. P., Stiller, G. P., von Clarmann, T., and Linden, A.: Global observations of stratospheric bromine monoxide from SCIAMACHY, Geophys. Res. Lett., 32, L20810, doi:10.1029/2005GL023839, 2005.

Sinnhuber, B.-M., Stiller, G., Ruhnke, R., von Clarmann, T., Kellmann, S., and Aschmann, J.: Arctic winter 2010/2011 at the brink of an ozone hole, Geophys. Res. Lett., 38, L24814, doi:10.1029/2011GL049784, 2011.

Sioris, C. E., Kovalenko, L. J., McLinden, C. A., Salawitch, R. J., Van Roozendael, M., Goutail, F., Dorf, M., Pfeilsticker, K., Chance, K., von Savigny, C., Liu, X., Kurosu, T. P., Pommereau, J.-P., Boesch, H., and Frerick, J.: Latitudinal and vertical distribution of bromine monoxide in the lower stratosphere from Scanning Imaging Absorption Spectrometer for Atmospheric Chartography limb scattering measurements, J. Geophys. Res.Atmos., 111, D14301, doi:10.1029/2005JD006479, 2006.

Toon, O. B., Starr, D. O., Jensen, E. J., Newman, P. A., Platnick, S., Schoeberl, M. R., Wennberg, P. O., Wofsy, S. C., Kurylo, M. J., Maring, H., Jucks, K. W., Craig, M. S., Vasques, M. F., Pfister, L., Rosenlof, K. H., Selkirk, H. B., Colarco, P. R., Kawa, S. R., Mace, G. G., Minnis, P., and Pickering, K. E.: Planning, implementation, and first results of the Tropical composition, cloud and climate coupling experiment (TC4), J. Geophys. Res.Atmos., 115, D00J04, doi:10.1029/2009JD013073, 2010. 
von Glasow, R., von Kuhlmann, R., Lawrence, M. G., Platt, U., and Crutzen, P. J.: Impact of reactive bromine chemistry in the troposphere, Atmos. Chem. Phys., 4, 2481-2497, doi:10.5194/acp-42481-2004, 2004.

Warwick, N. J., Pyle, J. A., Carver, G. D., Yang, X., Savage, N. H., O'Connor, F. M., and Cox, R. A.: Global modeling of biogenic bromocarbons, J. Geophys. Res.-Atmos., 111, D24305, doi:10.1029/2006JD007264, 2006.

Weigel, R., Borrmann, S., Kazil, J., Minikin, A., Stohl, A., Wilson, J. C., Reeves, J. M., Kunkel, D., de Reus, M., Frey, W., Lovejoy, E. R., Volk, C. M., Viciani, S., D’Amato, F., Schiller, C., Peter, T., Schlager, H., Cairo, F., Law, K. S., Shur, G. N., Belyaev, G. V., and Curtius, J.: In situ observations of new particle formation in the tropical upper troposphere: the role of clouds and the nucleation mechanism, Atmos. Chem. Phys., 11, 998310010, doi:10.5194/acp-11-9983-2011, 2011.
Yokouchi, Y., Hasebe, F., Fujiwara, M., Takashima, H., Shiotani, M., Nishi, N., Kanaya, Y., Hashimoto, S., Fraser, P., Toom-Sauntry, D., Mukai, H., and Nojiri, Y.: Correlations and emission ratios among bromoform, dibromochloromethane, and dibromomethane in the atmosphere, J. Geophys. Res.-Atmos., 110, D23309, doi:10.1029/2005JD006303, 2005. 